medRxiv preprint doi: https://doi.org/10.1101/2022.01.05.22268648; this version posted January 6, 2022. The copyright holder for this preprint (which was not certified by peer review) is the author/funder, who has granted medRxiv a license to display the preprint in perpetuity.

All rights reserved. No reuse allowed without permission.

\title{
Durability of Protection against COVID-19 Breakthrough Infections and Severe Disease by Vaccines in the United States
}

\author{
Amanda Zheutlin, $\mathrm{PhD}^{1^{*}}$, Miles Ott, $\mathrm{PhD}^{1^{*}}$, Ran Sun, $\mathrm{PhD}^{1}$, Natalia Zemlianskaia, $\mathrm{PhD}^{1}$, \\ Meagan Rubel, $\mathrm{PhD}^{1}$, Jennifer Hayden, $\mathrm{MPH}^{1}$, Breno Neri, $\mathrm{PhD}^{1}$, Tripthi Kamath, $\mathrm{PhD}^{1}$, Najat \\ Khan, $\mathrm{PhD}^{1}$, Sebastian Schneeweiss, MD, $\mathrm{ScD}^{2,3}$ and Khaled Sarsour, $\mathrm{PhD}^{1}$ \\ ${ }^{1}$ Data Science, Research \& Development, Janssen Pharmaceuticals \\ ${ }^{2}$ Department of Science, Aetion Inc., New York, NY \\ ${ }^{3}$ Division of Pharmacoepidemiology, Department of Medicine, Brigham and Women's Hospital \\ and Harvard Medical School \\ *Authors contributed equally
}

Abstract: 280 words

Text: 2,983 words

Contact information for corresponding author

Khaled Sarsour, $\mathrm{PhD}$

260 E Grand Ave.,

South San Francisco, CA 94080

ksarsour@its.jnj.com

\section{Funding}

This work was funded by Janssen Research \& Development.

\section{Conflicts of Interest}

Dr. Zheutlin, Dr. Ott, Dr. Sun, Dr. Zemlianskaia, Dr. Rubel, Ms. Hayden, Dr. Neri, Dr. Kamath, Dr. Khan and Dr. Sarsour are employees of Janssen R\&D, the manufacturer of Ad26.COV2.S.

Dr. Schneeweiss (ORCID\# 0000-0003-2575-467X) is participating in investigator-initiated grants to the Brigham and Women's Hospital from Boehringer Ingelheim unrelated to the topic of this study. He is a consultant to Aetion Inc. of which he owns equity. He did not receive consultancy fees from Janssen before, during, or after this study was conducted. His interests were declared, reviewed, and approved by the Brigham and Women's Hospital in accordance with their institutional compliance policies.

\section{Acknowledgements}

The authors thank the following team members for critical feedback during the development of the study protocol and/or review of findings: Penny Heaton (Janssen), Johan Van Hoof (Janssen), Deb Ricci (Janssen), Ray Harvey (Janssen), Sid Jain (Janssen), Xiaoying Wu (Janssen), Sophia Gallucci (Aetion), Ann Madsen (Aetion), and Mike Batech (Aetion). 
medRxiv preprint doi: https://doi.org/10.1101/2022.01.05.22268648; this version posted January 6, 2022. The copyright holder for this preprint (which was not certified by peer review) is the author/funder, who has granted medRxiv a license to display the preprint in perpetuity.

All rights reserved. No reuse allowed without permission.

\begin{abstract}
Objectives: Determine durability of protection by the three currently available COVID-19 vaccines in the United States (US) following primary vaccination against breakthrough infections, hospitalizations, and intensive care unit (ICU) admissions.
\end{abstract}

Methods: Using claims and laboratory data covering 168 million lives, we conducted a matched case-control study with fully vaccinated individuals between January 1 and September 7, 2021. Odds ratios (OR) for developing outcomes in months two through six following full vaccination were estimated relative to the first month after full vaccination for each vaccine separately.

Results: Evidence of waning protection against infections started in month 2 from vaccination for both BNT162b2 (OR [95\% CI] in month 6+, $2.93[2.72,3.15])$ and mRNA-1273 (OR [95\% CI] in month $6+, 2.76[2.51,3.04])$, and in month 4 for Ad26.COV2.S (OR [95\% CI] in month 5+, 1.31 $[1.18,1.47])$. Evidence of waning protection against hospitalization started in month 2 for BNT162b2 (OR [95\% CI], 3.97 [3.26, 4.83] in month 6+) and in month 3 for mRNA-1273 (OR 95\% CI, $1.66[1.26,2.19]$ in month $6+)$. There was no evidence of waning protection against hospitalization for Ad26.COV2.S (OR [95\% CI], $1.25[0.86,1.80]$ in month 5+). No waning of protection was observed at any time for ICU admissions for all three vaccines.

Conclusions: Following primary vaccination, all three vaccines showed strong and durable protection against ICU admissions. Ad26.COV2.S showed a more durable level of protection against breakthrough infections and hospitalizations in line with published evidence of its durable antibody and cellular immune response, although its Vaccine Effectiveness (VE) at baseline after a single-dose is lower than that for the two-dose mRNA vaccines. Additional studies are needed to understand durability following homologous or heterologous boosters. 
medRxiv preprint doi: https://doi.org/10.1101/2022.01.05.22268648; this version posted January 6, 2022. The copyright holder for this preprint (which was not certified by peer review) is the author/funder, who has granted medRxiv a license to display the preprint in perpetuity.

All rights reserved. No reuse allowed without permission.

\section{Introduction}

Randomized clinical trials have demonstrated high vaccine efficacy in protection against COVID19 infection for all three US authorized or approved vaccines (Ad26.COV2.S, BNT162b2 and mRNA-1273) ${ }^{1-3}$ and subsequent studies have confirmed high vaccine effectiveness (VE) against infection and severe disease in the real-world. ${ }^{4-13}$ Preliminary data on waning VE for the mRNA vaccines and opportunity for improved VE for the Janssen vaccine have prompted regulatory approval or emergency use authorization for booster doses in the US for all adults. Nonetheless, there is still limited understanding of the durability of vaccine protection among the general adult population, as well as against novel SARS-CoV-2 variants, including the delta variant (B.1.617.2) and its subtypes. As the immune responses do vary among the vaccines, there remains the potential that the vaccines have distinct durability properties that need to be studied robustly. Studies on the durability of all three US vaccines in the general population have been limited to date, with many focusing on high-risk populations ${ }^{13-19}$ or specific geographic areas. ${ }^{20-22}$ Furthermore, durability of response to initial vaccine regimens remains especially important for management of the pandemic globally, as much of the world remains unvaccinated or only recently vaccinated. As such, it is critical to assess the degree to which protection is sustained to inform on the need and timing for booster doses in the general adult population.

In this study, we report the durability of protection against COVID-19 in over 17 million vaccinated individuals following primary vaccination for each approved or authorized vaccine against breakthrough infections, hospitalizations, and intensive care unit (ICU) admissions, while accounting for calendar time, residential location, age, sex, and comorbid conditions. 
medRxiv preprint doi: https://doi.org/10.1101/2022.01.05.22268648; this version posted January 6, 2022. The copyright holder for this preprint (which was not certified by peer review) is the author/funder, who has granted medRxiv a license to display the preprint in perpetuity.

\section{Methods}

Study Design

We used a matched case-control design conducted with a cohort of vaccinated individuals to assess the durability of initial vaccine-induced protection against COVID-19 infections, hospitalizations, and ICU admissions between January 1 and September 7, 2021. To evaluate whether vaccineinduced protection wanes over time, we compared the odds of COVID-19 breakthrough infection, hospitalization, or ICU admission in each subsequent 28-day window (months 2 through 6+ since vaccination) relative to the first month since vaccination (reference month lasting 28 days). Here, durability was defined as relatively constant odds for the outcome of interest across time. Month 1 began the day after full vaccination, which was defined as 21-days following the final vaccination dose; day 22 is thus the beginning of the first month of follow-up (Figure 1). We selected this timeframe to allow for the 14 days required for full vaccination ${ }^{23}$ and an additional 7 -day washout period to ensure COVID-19-related outcomes included in our study were limited to those due to COVID-19 infections acquired after full vaccination. Since the CDC guidelines recommend waiting 5-7 days after exposure to get tested, ${ }^{24}$ test results and hospitalizations recorded soon after full vaccination (i.e., 15-21 days after the last dose) may reflect infections and exposures occurring prior to full vaccination.

The collection and analysis of these data did not qualify as human subjects research under the Common Rule and were not subject to institutional review board assessment. ${ }^{25-27}$ The New England institutional review board approved this exemption (no.1-9757-1). Upon reasonable request, researchers may get access to the data and analytics infrastructure for prespecified collaborative analyses. 
Data

We analyzed de-identified person-level longitudinal data captured from medical and pharmacy claims, laboratory tests and results, and hospital chargemaster data from over 70 sources in the US aggregated by HealthVerity. This database has been used in other COVID-19 research studies. ${ }^{28-}$

32 We drew cohorts for the current study from a broadly defined COVID-19 dataset where individuals were included based on having any documentation of COVID-19 related diagnoses, laboratory orders, procedures, treatments, or COVID-19 vaccinations. The dataset contained all major insurance types in the US in proportions representative of the US population: Medicaid (19\%), Medicare (14\%), commercial (60\%), and federal $(5 \%) \cdot{ }^{33}$ Race and ethnicity information was not available as they were considered personally identifiable information by HealthVerity.

\section{$\underline{\text { Population }}$}

We defined eligible individuals as adults aged 18 years or older who were vaccinated following the recommended immunization schedule. For mRNA-1273, two doses 28-42 days apart were required; for BNT62b2, two doses 21-42 days apart were required; and for Ad26.COV2.S, one dose was required. ${ }^{34}$ The first dose of mRNA-1273 or BNT62b2 must have been on January 1, 2021 or later; the single dose of Ad26.COV2.S must have been on February 27, 2021 or later. Cohort entry began 21 days after the last vaccine dose. Exclusion criteria are listed in Figure 1.

\section{Exposure}

The exposure of interest was months since cohort entry to the outcome of interest. We grouped 
medRxiv preprint doi: https://doi.org/10.1101/2022.01.05.22268648; this version posted January 6, 2022. The copyright holder for this preprint (which was not certified by peer review) is the author/funder, who has granted medRxiv a license to display the preprint in perpetuity.

All rights reserved. No reuse allowed without permission.

follow-up time (occurring between 21-days post completed vaccination and 7 September 2021) into five exposure categories: month 1 or reference month (1-28 days after follow-up started), month 2 (29-56 days), month 3 (57-84 days), month 4 (85-112 days), month 5 (113-140 days), and month $6+(140$ or more days).

\section{$\underline{\text { Cases and Controls }}$}

The first outcome of interest was incident breakthrough infection identified by either a COVID19 ICD-10-CM diagnosis code (U07.1, U07.2) or a positive polymerase chain reaction (PCR) laboratory test. The case date was defined as the date of the first occurrence of a relevant code or test result during the study period. We matched each case to up to 10 controls who did not have the outcome of interest at any point during the study period by matching exactly on the calendar date of the outcome, location (three-digit zip code), sex, age (5-year category), and Gagne comorbidity score category $(<2,2-3,4-5,6+)^{35}$ using risk set sampling $(\mathrm{RSS})^{36}$ without replacement (Figure 1).

We included incident hospitalization and ICU admission as additional outcomes to index more severe disease. A COVID-19-related hospitalization was defined as an inpatient hospital encounter during which a COVID-19 ICD-10-CM code (U07.1, U07.2) or positive PCR laboratory test result was recorded. For case events, we required the initial admission date to be during our study period to further avoid hospitalizations due to infections acquired prior to full vaccination. COVID-19related ICU admissions were defined as an inpatient hospital encounter as described above that additionally included an admission to an ICU. For both outcomes, the first of this type of event during the study period was considered the case event and the case event date was set as the hospital admission date. Controls were selected and matched as described above for breakthrough 
infections.

\section{$\underline{\text { Statistical Analysis }}$}

To assess the durability of protection, we fitted conditional logistic regression models separately for each vaccine and outcome combination, resulting in nine models. Conditional logistic regression models were used to condition on the matched group, each of which contained one case and up to 10 controls. This approach allowed for estimation of our effect of interest (time from vaccination) within individuals matched on factors that may increase the chance of a COVID-19related outcome. In the conditional logistic regression models, case status was the dependent variable while indicator variables for month 2 through month $6+$, using month 1 as the reference category was the independent variable. Generated ORs with 95\% Confidence Interval (OR, 95\% CI) measured change in baseline protection relative to the referent month. We also conducted sensitivity analyses for age and comorbidities. Because of the importance of understanding VE against COVID-19 outcomes, we translated OR into VE (Supplementary Methods).

In addition to this full dataset analysis for all 3 vaccines from January 1 to September 7, 2021, given the approval of the vaccines occurred at different timepoints and the participants prioritized for the initial vaccine roll-out in January and February 2020 where higher risk individuals with a greater proportion of older and more comorbid individuals, we also conducted supplemental analysis where the last dose of vaccination was on or after February 27, 2021 for all three vaccines

\section{(Supplementary Methods).}

\section{Results}

$\underline{\text { Vaccine Cohorts, Cases and Controls }}$ 
medRxiv preprint doi: https://doi.org/10.1101/2022.01.05.22268648; this version posted January 6, 2022. The copyright holder for this preprint (which was not certified by peer review) is the author/funder, who has granted medRxiv a license to display the preprint in perpetuity.

All rights reserved. No reuse allowed without permission.

Individuals fully vaccinated with one of the three authorized or approved vaccines in the US and meeting study inclusion and exclusion criteria represented the broader vaccinated cohorts from which our matched case-control samples were drawn (see study flowchart, Figure S1). Together, $17,017,435$ individuals were included in these cohorts, who were fully vaccinated in the US by the end of our study period (September 7, 2021). ${ }^{37}$ Overall vaccine cohorts differed in some demographic factors across vaccines (Table 1), reflecting differences in vaccine authorization and eligibility timing, as well as differences in distribution and availability. The average (mean) age in the Ad26.COV2.S cohort (50.9 years old) was slightly younger than those in the BNT162b2 (53.1) and mRNA-1273 (56.6 years old) cohorts. The Ad26.COV2.S cohort also had fewer women and fewer individuals with high $(\geq 2)$ Gagne comorbidity scores (52.0\% and $10.5 \%$, respectively), compared to the BNT162b2 (58.4\% and 13.1\%) and the mRNA-1273 (57.5\% and $13.3 \%)$ cohorts. The number of cases and matched controls for each outcome for each vaccine are listed in Table 2. Across vaccines and outcomes, the included cases represented $98 \%$ of all eligible cases.

\section{Durability of Protection against COVID-19 breakthrough infections}

Among those who were vaccinated with the Ad26.COV2.S vaccine, there was no evidence of waning protection against breakthrough infection in the first three months of follow-up. There was evidence of modest waning protection in month 4 (OR [95\% CI], $1.16[1.04,1.29])$ and in month 5+ (OR [95\% CI], $1.31[1.18,1.47])$ (Table 3 and Figure 2a). There was not sufficient follow-up in the Ad26.COV2.S group to include a category for $6+$ months. Among those who were vaccinated with either the BNT162b2 or mRNA-1273 vaccines, the odds of a breakthrough infection were successively higher for each month of follow-up (OR for month 6+ of BNT162b2 
medRxiv preprint doi: https://doi.org/10.1101/2022.01.05.22268648; this version posted January 6, 2022. The copyright holder for this preprint (which was not certified by peer review) is the author/funder, who has granted medRxiv a license to display the preprint in perpetuity. All rights reserved. No reuse allowed without permission.

$=2.93,95 \%$ CI $[2.72,3.15]$; OR for month $6+$ of mRNA-1273 $=2.76,95 \%$ CI $[2.51,3.04]$ ) (Table 3 and Figures 2b-2c).

Sensitivity analyses that stratified by age and comorbidity and alignment of calendar date, where the last dose of vaccination was on or after February 27, 2021 for all three vaccines showed the same trends as in the primary analyses (Figures S2-S3 and S5).

Corresponding VE estimates for each month of follow-up showed the highest baseline VE for mRNA-1273, followed by BNT162b2 and Ad26.COV2.S. The smallest reduction in VE over time was for Ad26.COV2.S, followed by mRNA-1273, and then BNT162b2 (Supplementary Results; Tables S1-S2, and Figures S4 and S6).

Durability of Protection against Hospitalization

There was no evidence of waning protection against COVID-19-related hospitalization for those who received Ad26.COV2.S vaccine (OR for month 5+ = 1.25, 95\% CI $[0.86,1.80]$ ) (Table 3 and Figure 2a). Among those who were vaccinated with the BNT162b2 vaccine, evidence of waning protection against COVID-19-related hospitalization was substantial and increased successively as compared to the first month of follow-up from vaccination (OR for month $6+=3.97,95 \% \mathrm{CI}$ [3.26, 4.83]) (Figure 2b). Among those vaccinated with the mRNA-1273 vaccine, the change in the odds of COVID-19-related hospitalization was less pronounced (OR for month $6+=1.66,95 \%$ CI [1.26, 2.19]) (Figure 2c).

Results from sensitivity analyses that stratified by age and comorbidity consistently showed no evidence of waning for Ad26.COV2.S (Figures S2-S3). For mRNA-1273, the sensitivity analyses are consistent with the primary analyses with some waning noted. For BNT162b2, the sensitivity 
medRxiv preprint doi: https://doi.org/10.1101/2022.01.05.22268648; this version posted January 6, 2022. The copyright holder for this preprint (which was not certified by peer review) is the author/funder, who has granted medRxiv a license to display the preprint in perpetuity. All rights reserved. No reuse allowed without permission.

analyses are also consistent with the primary analyses with substantial waning noted for protection against hospitalization.

When vaccination was on or after February 27, 2021, for all three vaccines, the patterns in waning were consistent with the primary analysis although less pronounced in magnitude (Figures S2S3). This could in part be given the initial cohorts vaccinated in Jan and Feb were older and had greater co-morbidities and were removed in this analysis.

Corresponding VE estimates for each month of follow-up showed the highest baseline VE for mRNA-1273, followed by BNT162b2 and Ad26.COV2.S. (Supplementary Results; Tables S1S2, and Figures S4 and S6).

Durability of Protection against ICU Admission

There was no evidence of waning protection against COVID-19-related ICU admissions at any point for any of the three vaccines (Table 3 and Figure 2). There were insufficient case numbers in any of the vaccine cohorts to have a follow-up category beyond month $4+$.

\section{Discussion}

Using claims data for over 168 million individuals in the US from January 1 to September 7, 2021, we used a matched case-control study design to assess the durability of protection against breakthrough infections, hospitalizations, and ICU admissions over time from full vaccination. The database used in this study was representative of the proportions of payer type used by the broader US population. ${ }^{33,37}$ By matching on potential confounding variables influencing the probability of these outcomes, including age, sex, high-risk comorbidities, the calendar date of the 
medRxiv preprint doi: https://doi.org/10.1101/2022.01.05.22268648; this version posted January 6, 2022. The copyright holder for this preprint (which was not certified by peer review) is the author/funder, who has granted medRxiv a license to display the preprint in perpetuity.

All rights reserved. No reuse allowed without permission.

outcome, and location (three-digit zip code), we were able to assess the durability of protection for each of the three vaccines among individuals at similar levels of risk.

Although, as seen in randomized trials, the level of efficacy of a single-dose Ad26.COV2.S vaccine is lower than that seen with two-dose mRNA vaccines, we found that the level of protection after vaccination with a single-dose Ad26.COV2.S vaccine was more durable than after vaccination with two-dose mRNA vaccines for breakthrough infections and hospitalizations. This observation is consistent with a more stable neutralizing antibody response for those inoculated with the Ad26.COV2.S vaccine as compared to the BNT162b2 and mRNA-1273 vaccines, ${ }^{38}$ potentially due to differences in the mechanism of action. ${ }^{39}$ All vaccines showed durable protection over the study period against ICU admission, showing strong sustained protection against critically severe disease.

For breakthrough infections and hospitalizations, the protection conferred by Ad26.COV2.S remained durable throughout the study period across all sub-groups of age and comorbidity. For mRNA-1273, evidence of waning protection was observed for breakthrough infections and some for hospitalization. For BNT162b2, evidence of more pronounced waning of protection was observed for both breakthrough infections and hospitalizations. (Figures S2-S3).

When we aligned the three-vaccine cohort entry date to February 27, 2021, the initial participants for mRNA-1273 and BNT162b2 who were vaccinated in January and February were removed from our analysis and as expected, the waning for both breakthrough infections and hospitalization was consistent with the primary analysis but of somewhat lower magnitude. This is expected in part given the participants prioritized for the initial vaccine roll-out in January and February 2020 where higher risk individuals with greater exposure to COVID-19, higher proportion of older and 
medRxiv preprint doi: https://doi.org/10.1101/2022.01.05.22268648; this version posted January 6, 2022. The copyright holder for this preprint (which was not certified by peer review) is the author/funder, who has granted medRxiv a license to display the preprint in perpetuity.

All rights reserved. No reuse allowed without permission.

more comorbid individuals. This may be driven by waning immune responses in older and more comorbid patients as has been observed in other studies. Continued investigation as datasets mature is warranted to fully understand the complete durability profile of each of the vaccines.

Our study was designed to compare the odds of outcome events from later periods to a period soon after full vaccination. A strength of this design is that it avoids the need for an unvaccinated control group, which may be subject to confounding and underreporting. ${ }^{4}$ However, as the clinical relevance of the observed ORs can be difficult to interpret without incorporating assumptions about incidence rate in the population during the study period, we indirectly estimated baseline and subsequent VE for each vaccine and outcome (Supplementary Methods and Results). Our estimated VEs are consistent with clinical trial results ${ }^{1-3}$ and many prior studies in real-world settings, ${ }^{4-13,40}$ (Tables S1-S2 and Figures S4 and S6). Consistent with the observed ORs, for infections, VE for single-dose Ad26.COV2.S remained stable across the study period, while twodose mRNA vaccines showed higher baseline VE with larger reductions over the study period, consistent with prior reports (Figure S7). ${ }^{19,22,41-44}$ Fewer studies have estimated durability over time for hospitalizations after vaccination with Ad26.COV2.S. ${ }^{13,19,21,41,43}$ Nonetheless, our results showing no waning for Ad26.COV2.S hospitalizations and waning for mRNA-1273 and BNT162b2, with more pronounced waning for BNT162b2 that was generally consistent with prior work. $^{13,20,21,41,42,44-46}$ (Figure S8).

The size of our study allowed us to assess durability over a longer period, including periods where different strains were dominant. ${ }^{47}$ Additionally, our findings extend prior reports of durability, which have been done in selected populations ${ }^{48}$ or by studying a subset of vaccine products or COVID-19-related outcomes. ${ }^{14,16,18,49-51}$ Few studies have assessed durability over time for 
medRxiv preprint doi: https://doi.org/10.1101/2022.01.05.22268648; this version posted January 6, 2022. The copyright holder for this preprint (which was not certified by peer review) is the author/funder, who has granted medRxiv a license to display the preprint in perpetuity.

All rights reserved. No reuse allowed without permission.

hospitalizations and ICU admissions. To our knowledge, our study is the first to report durability of protection against ICU admissions for a US population. This is one strength of this study as hospitalizations and ICU admissions can be studied with high accuracy in national claims databases.

Several limitations should be considered when interpreting our results. First, direct comparisons between vaccines should be made with appropriate caution as there may remain baseline differences between the three vaccine cohorts. However, multiple sets of sensitivity analyses by age, comorbidities, and cohort entry time helped mitigate any observable differences. Second, although we reduced differences between cases and controls that could affect the probability of COVID-19-related outcomes through matching, there could be remaining unmeasured effects such as occupation-related exposure. Third, this study did not directly adjust for the strain of infection, although matching on calendar time and location likely accounted for that. However, observed vaccine waning may still be confounded by the reduction in protection against novel variants. ${ }^{48}$ Finally, this study relied primarily on open claims, which means other COVID-19-related medical encounters may have occurred within our population that we did not observe. However, individuals included in our study had observable vaccination records as well as healthcare utilization prior to vaccination, so observability should not be a significant limitation.

In summary, durable protection against ICU admissions was observed for all three vaccines. However, the durability of protection against breakthrough infections and hospitalizations varied among the vaccines. We found that the level of VE at baseline against infections and hospitalizations provided by single-dose Ad26.COV2.S, albeit lower, was more durable than that provided by both two-dose mRNA vaccines. Trends remained consistent when stratifying by age 
medRxiv preprint doi: https://doi.org/10.1101/2022.01.05.22268648; this version posted January 6, 2022. The copyright holder for this preprint (which was not certified by peer review) is the author/funder, who has granted medRxiv a license to display the preprint in perpetuity.

All rights reserved. No reuse allowed without permission.

and comorbidities. As the COVID-19 pandemic continues, and as the vaccination standard of care in some countries becomes three doses of the mRNA vaccines or two doses of Ad26.COV2.S, further investigation is critical to understand the level of protection and the durability of response over longer periods and in response to homologous and heterologous boosting. 
medRxiv preprint doi: https://doi.org/10.1101/2022.01.05.22268648; this version posted January 6, 2022. The copyright holder for this preprint (which was not certified by peer review) is the author/funder, who has granted medRxiv a license to display the preprint in perpetuity. All rights reserved. No reuse allowed without permission.

\section{References}

1. Polack FP, Thomas SJ, Kitchin N, et al. Safety and Efficacy of the BNT162b2 mRNA Covid-19 Vaccine. New England Journal of Medicine. 2020;383(27):2603-2615. doi:10.1056/nejmoa2034577

2. Sadoff J, Gray G, Vandebosch A, et al. Safety and Efficacy of Single-Dose Ad26.COV2.S Vaccine against Covid-19. New England Journal of Medicine. 2021;384(23):2187-2201. doi:10.1056/nejmoa2101544

3. Baden LR, el Sahly HM, Essink B, et al. Efficacy and Safety of the mRNA-1273 SARSCoV-2 Vaccine. New England Journal of Medicine. 2021;384(5):403-416. doi:10.1056/nejmoa2035389

4. Polinski JM, Weckstein AR, Batech M, et al. Effectiveness of the single-dose Ad26.COV2.S COVID vaccine. Posted September 16, 2021. doi:10.1101/2021.09.10.21263385

5. Puranik A, Lenehan 1+ PJ, Silvert E, et al. Comparison of two highly-effective mRNA vaccines for COVID-19 during periods of Alpha and Delta variant prevalence. doi:10.1101/2021.08.06.21261707

6. Thompson MG, Burgess JL, Naleway AL, et al. Interim Estimates of Vaccine Effectiveness of BNT162b2 and MRNA-1273 COVID-19 Vaccines in Preventing SARSCoV-2 Infection among Health Care Personnel, First Responders, and Other Essential and Frontline Workers-Eight U.S. Locations, December 2020-March 2021.; 2021. https://preprints.jmir.org/preprint/28925

7. Dagan N, Barda N, Kepten E, et al. BNT162b2 mRNA Covid-19 vaccine in a nationwide mass vaccination setting. New England Journal of Medicine. 2021;384(15):1412-1423. doi:10.1056/nejmoa2101765

8. Tartof SY, Slezak JM, Fischer H, et al. Effectiveness of mRNA BNT162b2 COVID-19 vaccine up to 6 months in a large integrated health system in the USA: a retrospective cohort study. Lancet (London, England). Published online October 4, 2021. doi:10.1016/S0140-6736(21)02183-8

9. Haas EJ, Angulo FJ, McLaughlin JM, et al. Impact and effectiveness of mRNA BNT162b2 vaccine against SARS-CoV-2 infections and COVID-19 cases, hospitalisations, and deaths following a nationwide vaccination campaign in Israel: an observational study using national surveillance data. The Lancet. 2021;397(10287):18191829. doi:10.1016/S0140-6736(21)00947-8

10. Tenforde MW, Self WH, Naioti EA, et al. Sustained effectiveness of Pfizer-BioNTech and Moderna vaccines against COVID-19 associated hospitalizations among adults — United States, March-July 2021. MMWR Morb Mortal Wkly Rep. 2021;70(34):1156-1162. https://www.cdc.gov/mmwr

11. Gray GE, Collie S, Garrett N, et al. Vaccine effectiveness against hospital admission in South African health care workers who received a homologous booster of Ad26.COV2 during an Omicron COVID19 wave: Preliminary Results of the Sisonke 2 Study. medRxiv. Posted December 29, 2021. doi: https://doi.org/10.1101/2021.12.28.21268436

12. RIVM COVID-19 Epidemiology and Surveillance Team. Effectiveness of COVID-19 vaccination against SARS-CoV-2 infection in the Delta period. National Institute for Public Health and the Environment, Ministry of Health, Welfare and Sport, Netherlands. Published on December 16, 2021. https://www.rivm.nl/documenten/effectiviteit-vancovid-19-vaccinatie-tegen-sars-cov-2-infectie-in-delta-periode 
medRxiv preprint doi: https://doi.org/10.1101/2022.01.05.22268648; this version posted January 6, 2022. The copyright holder for this preprint (which was not certified by peer review) is the author/funder, who has granted medRxiv a license to display the preprint in perpetuity. All rights reserved. No reuse allowed without permission.

13. Self WH, Tenforde MW, Rhoads JP, et al. Comparative effectiveness of Moderna, PfizerBioNTech, and Janssen (Johnson \& Johnson) vaccines in preventing COVID-19 hospitalizations among adults without immunocompromising conditions - United States, March-August 2021. MMWR Morb Mortal Wkly Rep. Published online September 24, 2021:1337-1343. https://www.cdc.gov/mmwr

14. Tenforde MW, Self WH, Adams K, et al. Association Between mRNA Vaccination and COVID-19 Hospitalization and Disease Severity. JAMA. 2021;326(20):2043-2054. doi:10.1001/jama.2021.19499

15. Poukka E, Baum U, Palmu A, et al. Cohort study of covid-19 vaccine effectiveness among healthcare workers in Finland, December 2020 - October 2021. Vaccine. 2021. https://doi.org/10.1016/j.vaccine.2021.12.032

16. Hagan LM, Mccormick DW, Lee C, et al. Outbreak of SARS-CoV-2 B.1.617.2 (delta) variant infections among incarcerated persons in a federal prison-Texas, July-August 2021. Morbidity and Mortality Weekly Report . 2021;70(38):1349-1354. https://stacks.

17. Rovida F, Cassaniti I, Paolucci Stefania, et al. SARS-CoV-2 vaccine breakthrough infections with the alpha variant are asymptmatic or mildly symptomatic among health care workers. medRxiv. Posted July 3, 2021. doi:10.1101/2021.06.29.21259500

18. Nunes B, Rodrigues AP, Kislaya I, et al. mRNA vaccine effectiveness against COVID-19related hospitalisations and deaths in older adults: A cohort study based on data linkage of national health registries in Portugal, February to August 2021. Eurosurveillance. 2021;26(38). doi:10.2807/1560-7917.ES.2021.26.38.2100833

19. de Gier B, Andeweg S, Backer JA, et al. Vaccine effectiveness against SARS-CoV-2 transmission to household contacts during dominance of delta variant (B.1.617.2), AugustSeptember 2021, the Netherlands. Eurosurveillance. 2021 Nov;26(44):2100977. doi:10.1101/2021.10.14.21264959

20. Liu C, Lee J, Ta C, et al. A retrospective analysis of COVID-19 mRNA vaccine breakthrough infections-risk factors and vaccine effectiveness. medRxiv. Posted October 07, 2021. doi:10.1101/2021.10.05.21264583

21. Rosenberg ES, Dorabawila V, Easton D, et al. COVID-19 vaccine effectiveness by product and timing in New York state. medRxiv. Posted October 9, 2021.

doi:10.1101/2021.10.08.21264595

22. Robles-Fontán MM, Nieves EG, Cardona-Gerena I, Irizarry RA. Time-varying effectiveness of the mRNA-1273, BNT162b2 and Ad26.COV2.S vaccines against SARSCoV-2 infections and COVID-19 hospitalizations and deaths: an analysis based on observational data from Puerto Rico. medRxiv. Posted October 18, 2021. doi:10.1101/2021.10.17.21265101

23. Centers for Disease Control and Prevention. When You've Been Fully Vaccinated. Accessed October 5, 2021. https://www.cdc.gov/coronavirus/2019-ncov/vaccines/fullyvaccinated.html

24. Centers for Disease Control and Prevention. COVID-19 Quarantine and Isolation. Accessed November 17, 2021. https://www.cdc.gov/coronavirus/2019-ncov/yourhealth/quarantine-isolation.html

25. Forrow S, Campion DM, Herrinton LJ, et al. The organizational structure and governing principles of the Food and Drug Administration's Mini-Sentinel pilot program.

Pharmacoepidemiology and Drug Safety. 2012;21(SUPPL. 1):12-17.

doi:10.1002/pds.2242 
medRxiv preprint doi: https://doi.org/10.1101/2022.01.05.22268648; this version posted January 6, 2022. The copyright holder for this preprint

(which was not certified by peer review) is the author/funder, who has granted medRxiv a license to display the preprint in perpetuity.

All rights reserved. No reuse allowed without permission.

26. Rosati K, Jorgensen N, Soliz M, Plc B, Evans BJ. HIPAA and Common Rule Compliance in the Sentinel Initiative.; 2018.

27. Mcgraw D, Rosati K, Evans B. A policy framework for public health uses of electronic health data. Pharmacoepidemiology and Drug Safety. 2012;21(SUPPL. 1):18-22.

doi:10.1002/pds.2319

28. Harvey RA, Rassen JA, Kabelac CA, et al. Association of SARS-CoV-2 seropositive antibody test with risk of future infection. JAMA Internal Medicine. 2021;181(5):672-679. doi:10.1001/jamainternmed.2021.0366

29. Murk W, Gierada M, Fralick M, Weckstein A, Klesh R, Rassen JA. Diagnosis-wide analysis of COVID-19 complications: an exposure-crossover study. Canadian Medical Association Journal. 2021;193(1):E10-E18. doi:10.1503/cmaj.201686

30. Schneeweiss MC, Leonard S, Weckstein A, Schneeweiss S, Rassen JA. Reninangiotensin-aldosterone-system inhibitor use in patients with COVID-19 infection and prevention of serious events: a cohort study in commercially insured patients in the US. medRxiv. Posted July 24, 2020. doi:10.1101/2020.07.22.20159855

31. Gordon DE, Hiatt J, Bouhaddou M, et al. Comparative host-coronavirus protein interaction networks reveal pan-viral disease mechanisms. Science. 2020;370(6521). doi:10.1126/science.abe9403

32. HealthVerity. HealthVerity Marketplace. Accessed December 1, 2021. https://healthverity.com/solutions/healthverity-marketplace/

33. Keisler-Starkey K, Bunch LN. Health Insurance Coverage in the United States: 2019.; 2020. https://www.census.gov/library/publications/2020/demo/p60-271.html

34. Centers for Disease Control and Prevention. COVID-19 Vaccines that Require 2 Shots. Accessed October 5, 2021. https://www.cdc.gov/coronavirus/2019-ncov/vaccines/second$\underline{\text { shot.html }}$

35. Gagne JJ, Glynn RJ, Avorn J, Levin R, Schneeweiss S. A combined comorbidity score predicted mortality in elderly patients better than existing scores. Journal of Clinical Epidemiology. 2011;64(7):749-759. doi:10.1016/j.jclinepi.2010.10.004

36. Wacholder S, McLaughlin JK, Silverman DT, Mandel JS. Selection of controls in casecontrol studies: I. principles. American Journal of Epidemiology. 1992;135(9):1019-1028. doi:10.1093/oxfordjournals.aje.a116396

37. Centers for Disease Control and Prevention. COVID data tracker: trends in number of COVID-19 vaccinations in the US. Accessed December 2, 2021. https://covid.cdc.gov/covid-data-tracker/\#vaccination-trends_vacctrends-fully-cum

38. Food and Drug Administration. Vaccines and Related Biological Products Advisory Committee October 14-15, 2021 Briefing Document - Sponsor (Janssen).; 2021. Accessed December 19, 2021. https://www.fda.gov/media/152954/download

39. Collier A ris Y, Yu J, McMahan K, et al. Differential kinetics of immune responses elicited by covid-19 vaccines. New England Journal of Medicine. 2021;385(21):1-3. doi: 10.1056/NEJMc2115596

40. Bruxvoort KJ, Sy LS, Qian L, et al. Real-World Effectiveness of the MRNA-1273 Vaccine against COVID-19: Interim Results from a Prospective Observational Cohort Study. Available at SSRN: https://ssrn.com/abstract=3916094 or http://dx.doi.org/10.2139/ssrn.3916094 
medRxiv preprint doi: https://doi.org/10.1101/2022.01.05.22268648; this version posted January 6, 2022. The copyright holder for this preprint

(which was not certified by peer review) is the author/funder, who has granted medRxiv a license to display the preprint in perpetuity.

All rights reserved. No reuse allowed without permission.

41. Lin DY, Gu Y, Wheeler B, et al. Effectiveness of covid-19 vaccines in the United States over 9 months: Surveillance data from the state of North Carolina. medRxiv. Posted October 26, 2021. doi:10.1101/2021.10.25.21265304

42. Skowronski DM, Setayeshgar S, Febriani Y, et al. Two-dose SARS-CoV-2 vaccine effectiveness with mixed schedules and extended dosing intervals: test-negative design studies from British Columbia and Quebec, Canada. medRxiv. doi:10.1101/2021.10.26.21265397

43. Martinex-Baz I, Trobajo-Sanmartin C, Mlquelelz A, et al. Product-specific COVID-19 vaccine effectiveness against secondary infection in close contacts, Navarre, Spain, April to August 2021. Eurosurveillance. Published online September 21, 2021:1-7. doi:10.2807/1560-7917

44. Sharma A, Oda G, Holodniy M. COVID-19 vaccine breakthrough infections in veterans health administration. medRxiv. Posted September 26, 20221.

doi:10.1101/2021.09.23.21263864

45. Chemaitelly H, Tang P, Hasan MR, et al. Waning of BNT162b2 vaccine protection against SARS-CoV-2 infection in Qatar. New England Journal of Medicine. Published online October 6, 2021. doi:10.1056/nejmoa2114114

46. Paz-Bailey G, Sternberg M, Kugeler K, et al. Covid-19 rates by time since vaccination during delta variant predominance. Published online December 20, 2021.

doi:10.1056/EVIDoa2100057

47. Harcourt J, Tamin A, Lu X, et al. Isolation and characterization of SARS-CoV-2 from the first US COVID-19 patient. bioRxiv. Posted March 7, 2020.

doi:10.1101/2020.03.02.972935

48. Verani JR, Baqui AH, Broome C v., et al. Case-control vaccine effectiveness studies: Data collection, analysis and reporting results. Vaccine. 2017;35(25):3303-3308.

doi:10.1016/j.vaccine.2017.04.035

49. Andrews N, Tessier E, Stowe J, Gower C, Kirsebom F, Simmons R, Gallagher E, Chand M, Brown K, Ladhani S, Ramsay M. Vaccine effectiveness and duration of protection of Comirnaty, Vaxzevria and Spikevax against mild and severe COVID-19 in the UK. medRxiv. Posted October 6, 2021.

50. Lopez Bernal J, Andrews N, Gower C, et al. Effectiveness of Covid-19 Vaccines against the B.1.617.2 (delta) Variant. New England Journal of Medicine. 2021;385(7):585-594. doi:10.1056/nejmoa2108891

51. Grannis SJ, Rowley EA, Ong TC, et al. Interim estimates of covid-19 vaccine effectiveness against covid-19-associated emergency department or urgent care clinic encounters and hospitalizations among adults during SARS-CoV-2 B. 1.617. 2 (delta) variant predominance_-nine states, June-August 2021. Morbidity and Mortality Weekly Report. 2021;70(37):1291 
medRxiv preprint doi: https://doi.org/10.1101/2022.01.05.22268648; this version posted January 6, 2022. The copyright holder for this preprint (which was not certified by peer review) is the author/funder, who has granted medRxiv a license to display the preprint in perpetuity. All rights reserved. No reuse allowed without permission.

Table 1. Characteristics of vaccine recipients for three vaccine cohorts.

\begin{tabular}{|c|c|c|c|}
\hline & Ad26.COV2.S & BNT162b2 & mRNA-1273 \\
\hline $\mathrm{N}$ & $1,761,498$ & $7,903,410$ & $7,352,527$ \\
\hline Age, mean (sd) & $50.9(17.5)$ & $53.1(19.4)$ & $56.6(18.8)$ \\
\hline \multicolumn{4}{|l|}{ Age group, n (\%) } \\
\hline $18-24$ & $156,961(8.9 \%)$ & $683,915(8.7 \%)$ & $457,258(6.2 \%)$ \\
\hline $25-29$ & $98,955(5.6 \%)$ & $451,780(5.7 \%)$ & $333,920(4.5 \%)$ \\
\hline $30-34$ & $111,886(6.4 \%)$ & $512,443(6.5 \%)$ & $379,781(5.2 \%)$ \\
\hline $35-39$ & $123,369(7.0 \%)$ & $537,280(6.8 \%)$ & $407,096(5.5 \%)$ \\
\hline $40-44$ & $130,393(7.4 \%)$ & $544,381(6.9 \%)$ & $422,532(5.7 \%)$ \\
\hline $45-49$ & $144,644(8.2 \%)$ & $573,498(7.3 \%)$ & $451,982(6.1 \%)$ \\
\hline $50-54$ & $181,413(10.3 \%)$ & $681,287(8.6 \%)$ & $569,539(7.7 \%)$ \\
\hline $55-59$ & $213,464(12.1 \%)$ & $797,898(10.1 \%)$ & $699,247(9.5 \%)$ \\
\hline $60-64$ & $218,591(12.4 \%)$ & $869,285(11.0 \%)$ & $813,055(11.1 \%)$ \\
\hline $65-69$ & $143,103(8.1 \%)$ & $662,119(8.4 \%)$ & $907,660(12.3 \%)$ \\
\hline $70-74$ & $104,923(6.0 \%)$ & $553,754(7.0 \%)$ & $766,263(10.4 \%)$ \\
\hline $75-79$ & $62,574(3.6 \%)$ & $371,754(4.7 \%)$ & $485,138(6.6 \%)$ \\
\hline $80-84$ & $32,566(1.8 \%)$ & $230,994(2.9 \%)$ & $274,499(3.7 \%)$ \\
\hline $85+$ & $38,455(2.2 \%)$ & $432,561(5.5 \%)$ & $383,911(5.2 \%)$ \\
\hline \multicolumn{4}{|l|}{ Gender, n (\%) } \\
\hline Male & $845,728(48.0 \%)$ & $3,286,709(41.6 \%)$ & $3,125,010(42.5 \%)$ \\
\hline Female & $915,727(52.0 \%)$ & $4,616,322(58.4 \%)$ & $4,227,255(57.5 \%)$ \\
\hline \multicolumn{4}{|l|}{$\begin{array}{l}\text { Gagne combined } \\
\text { comorbidity score }\end{array}$} \\
\hline mean (sd) & $0.41(1.28)$ & $0.53(1.48)$ & $0.52(1.46)$ \\
\hline median (IQR) & $0.0(0.0)$ & $0.0(1.0)$ & $0.0(1.0)$ \\
\hline \multicolumn{4}{|l|}{$\begin{array}{l}\text { Comorbidity score } \\
\text { category, n }(\%)\end{array}$} \\
\hline$<2$ & $1,576,908(89.5 \%)$ & $6,865,542(86.9 \%)$ & $6,375,144(86.7 \%)$ \\
\hline $2-3$ & $126,114(7.2 \%)$ & $662,133(8.4 \%)$ & $635,831(8.6 \%)$ \\
\hline $4-5$ & $34,213(1.9 \%)$ & $212,538(2.7 \%)$ & $199,039(2.7 \%)$ \\
\hline $6+$ & $24,263(1.4 \%)$ & $163,197(2.1 \%)$ & $142,513(1.9 \%)$ \\
\hline $\begin{array}{l}\text { Medicaid insured, } \mathrm{n} \\
(\%)\end{array}$ & $154,072(8.7 \%)$ & $570,587(7.2 \%)$ & $554,110(7.5 \%)$ \\
\hline
\end{tabular}

Note. sd: standard error; IQR: interquartile range. 
medRxiv preprint doi: https://doi.org/10.1101/2022.01.05.22268648; this version posted January 6, 2022. The copyright holder for this preprint (which was not certified by peer review) is the author/funder, who has granted medRxiv a license to display the preprint in perpetuity.

All rights reserved. No reuse allowed without permission.

Table 2. Number of cases and matched controls by vaccine and outcome

\begin{tabular}{llll}
\hline Vaccine & Outcome & Cases & Matched controls \\
\hline Ad26.COV2.S & Infection & 7,945 & 67,771 \\
& Hospitalization & 823 & 5,991 \\
BNT162b2 & ICU admission & 82 & 595 \\
& Infection & 27,797 & 261,200 \\
& Hospitalization & 4,525 & 42,233 \\
mRNA-1273 & ICU admission & 320 & 2,989 \\
& Infection & 15,694 & 148,709 \\
& Hospitalization & 2,070 & 19,176 \\
& ICU admission & 212 & 2,057 \\
\hline
\end{tabular}


Table 3. OR assessing durability of baseline vaccine protection against infections, hospitalizations, and ICU admissions.

\begin{tabular}{|c|c|c|c|}
\hline & $\begin{array}{l}\text { Breakthrough Infection } \\
\mathrm{OR}^{1}(95 \% \mathrm{CI})\end{array}$ & $\begin{array}{l}\text { Hospitalization } \\
\text { OR }^{1}(95 \% \mathrm{CI})\end{array}$ & $\begin{array}{l}\text { ICU } \\
\text { OR }^{1}(95 \% \mathrm{CI})\end{array}$ \\
\hline \multicolumn{4}{|c|}{ Ad26.COV2.S } \\
\hline Month 1 & 1 (Reference) & 1 (Reference) & 1 (Reference) \\
\hline Month 2 & $1.03(0.94,1.14)$ & $1.01(0.76,1.34)$ & $0.96(0.39,2.41)$ \\
\hline Month 3 & $0.99(0.89,1.11)$ & $1.15(0.83,1.60)$ & $1.89(0.65,5.51)$ \\
\hline Month 4 & $1.16(1.04,1.29)$ & $1.11(0.79,1.56)$ & $1.40(0.43,4.55)^{2}$ \\
\hline $\begin{array}{l}\text { Month } 5 \text { or } \\
\text { after }\end{array}$ & $1.31(1.18,1.47)^{3}$ & $1.25(0.86,1.80)^{3}$ & \\
\hline \multicolumn{4}{|l|}{ BNT162b2 } \\
\hline Month 1 & 1 (Reference) & 1 (Reference) & 1 (Reference) \\
\hline Month 2 & $1.28(1.21,1.36)$ & $1.26(1.10,1.44)$ & $1.20(0.80,1.80)$ \\
\hline Month 3 & $1.68(1.58,1.78)$ & $1.81(1.55,2.12)$ & $0.73(0.44,1.21)$ \\
\hline Month 4 & $1.99(1.87,2.12)$ & $2.45(2.05,2.92)$ & $1.36(0.80,2.30)^{2}$ \\
\hline Month 5 & $2.37(2.21,2.54)$ & $3.54(2.93,4.27)$ & \\
\hline $\begin{array}{l}\text { Month } 6 \text { or } \\
\text { after }\end{array}$ & $2.93(2.72,3.15)$ & $3.97(3.26,4.83)$ & \\
\hline \multicolumn{4}{|c|}{ mRNA-1273 } \\
\hline Month 1 & 1 (Reference) & 1 (Reference) & 1 (Reference) \\
\hline Month 2 & $1.21(1.13,1.30)$ & $1.08(0.91,1.29)$ & $0.62(0.40,0.97)$ \\
\hline Month 3 & $1.49(1.38,1.61)$ & $1.23(1.01,1.51)$ & $0.73(0.43,1.23)$ \\
\hline Month 4 & $1.83(1.68,1.98)$ & $1.41(1.12,1.77)$ & $1.17(0.64,2.13)^{2}$ \\
\hline Month 5 & $2.15(1.97,2.35)$ & $1.62(1.27,2.07)$ & \\
\hline $\begin{array}{l}\text { Month } 6 \text { or } \\
\text { after }\end{array}$ & $2.76(2.51,3.04)$ & $1.66(1.26,2.19)$ & \\
\hline
\end{tabular}

${ }^{1}$ ORs are matched and conditioned on age group, sex, Gagne comorbidity index score category, three-digit zip, and calendar date.

2 The last time category for ICU was month 4 or after.

${ }^{3}$ The last time category for Ad26.COV2.S for infections and hospitalizations was month 5 or after. 
medRxiv preprint doi: https://doi.org/10.1101/2022.01.05.22268648; this version posted January 6, 2022. The copyright holder for this preprint (which was not certified by peer review) is the author/funder, who has granted medRxiv a license to display the preprint in perpetuity.

All rights reserved. No reuse allowed without permission.

Figure 1. Schematic of the study design.

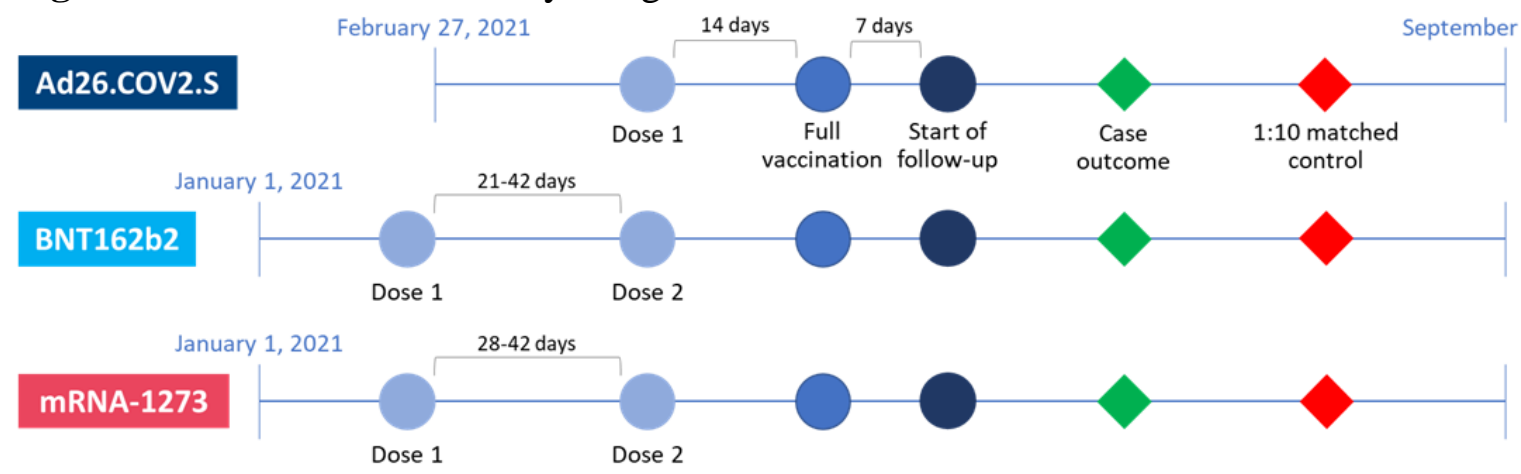

Control match criteria

1. No record of outcome prior to calendar time of match

2. 5-year age category

3. Gagne comorbidity score category

4. Exact match on zip-3

5. Exact match on sex

Note: Cases and controls are matched on calendar time and not on follow-up time, and so they do not appear on the same point in time in this follow up time schematic 
medRxiv preprint doi: https://doi.org/10.1101/2022.01.05.22268648; this version posted January 6, 2022. The copyright holder for this preprint (which was not certified by peer review) is the author/funder, who has granted medRxiv a license to display the preprint in perpetuity. All rights reserved. No reuse allowed without permission.

Figure 2. Odds ratios (OR) and 95\% CI assessing durability of baseline vaccine protection against COVID-19 breakthrough infections, hospitalizations, and ICU admissions.

\section{a) Ad26.COV2.S}
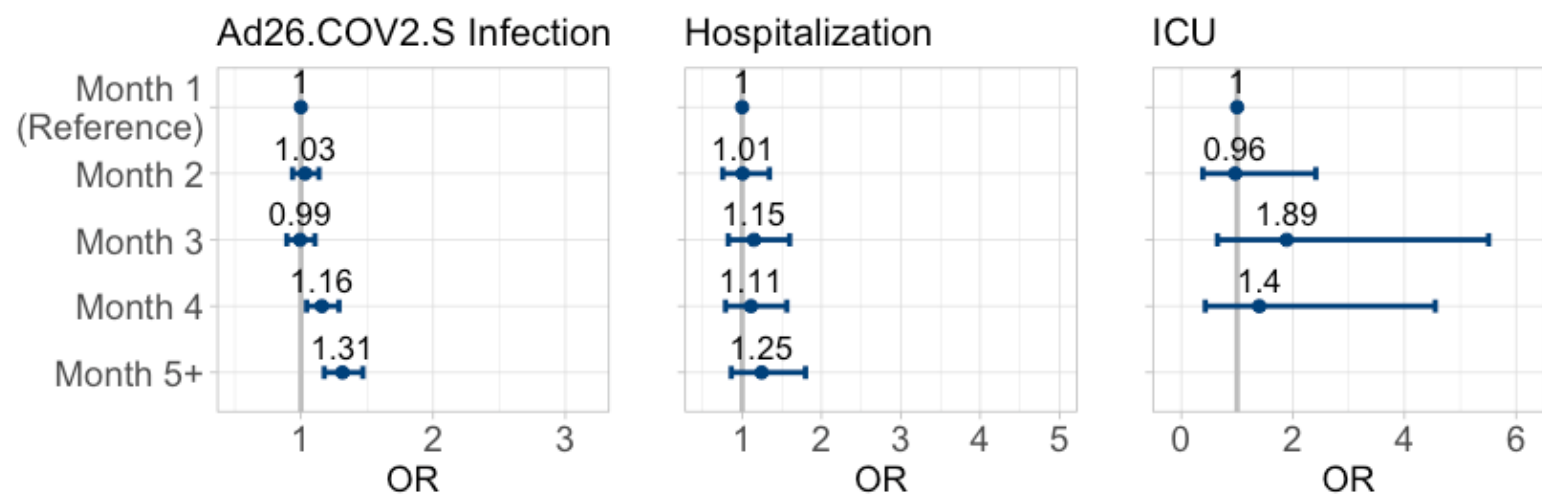

b) BNT162b2
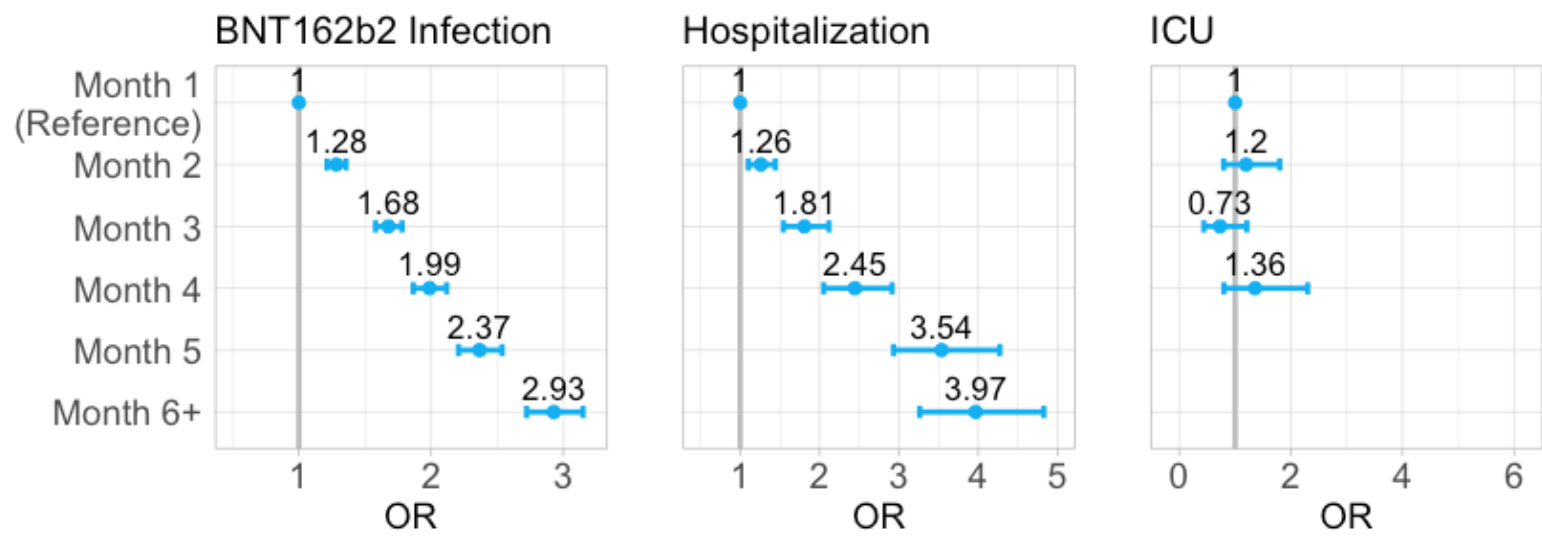

c) mRNA-1273
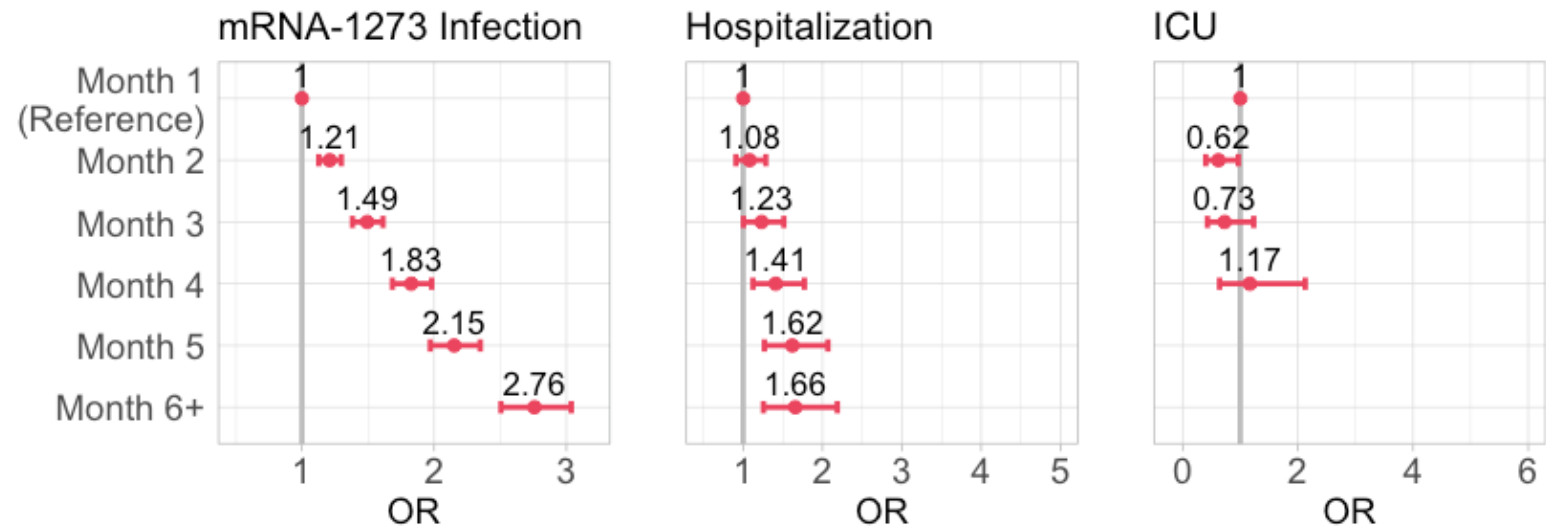

Notes: (1) Baseline protection on Month 1 (Reference) for the three vaccines may differ. In the Supplementary Materials, for example, we estimate VE against infections and hospitalizations in Month 1 for Ad26.COV2.S as $74 \%$ and $81 \%$, for BNT162b2 as $88 \%$ and $89 \%$, and for mRNA-1273 as 92\% and 94\% (Table S1). (2) The last time category for Ad26.COV2.S was month 5 or after. (3) The last time category for ICU was month 4 or after. 
medRxiv preprint doi: https://doi.org/10.1101/2022.01.05.22268648; this version posted January 6, 2022. The copyright holder for this preprint (which was not certified by peer review) is the author/funder, who has granted medRxiv a license to display the preprint in perpetuity. All rights reserved. No reuse allowed without permission.

\section{Supplementary Materials}

\section{Supplementary Methods}

\section{$\underline{\text { Additional data details }}$}

For the more than 168 million individuals included in the source data, all available health data regardless of relation to COVID-19 were included. Both open (claims sent from providers to payers) and closed (adjudicated) claims were used. While open claims do not include participant enrollment (limiting certainty of observability), they capture events closer to real time since there is no lag caused by the adjudication process. To avoid inclusion of persons whose care would not be continuously available in this database (e.g., persons that do not routinely receive medical care from an included healthcare system), we required prior utilization in the two years preceding vaccination for inclusion (see 'Population' below for more details).

\section{$\underline{\text { Exclusion criteria }}$}

We excluded 1) individuals with any positive diagnostic or antibody laboratory test or a diagnostic ICD-10 code for COVID-19 before cohort entry; 2) individuals with missing age, sex, or geographic information (three-digit zip code); 3) individuals who received mismatched series of COVID-19 vaccines (e.g., one dose of BNT162b2 followed by one dose of mRNA-1273, or vice versa); 4) individuals who received more or fewer than the required number of doses (e.g., individuals who received a second dose of the Ad26.COV2.S vaccine); and 5) individuals with no medical claims in the two years before their last required vaccine dose to ensure observability of patient information.

\section{$\underline{\text { Sensitivity analyses }}$}

In the US, the Food and Drug Administration authorized or approved three vaccines: the two-dose regimen of BNT162b2 (Pfizer-BioNTech, authorized on December 11, 2020 and approved on August 23, 2021) ${ }^{1}$ and mRNA-1273 (Moderna, authorized on December 18, 2020) COVID-19 vaccines, ${ }^{2}$ and the single dose regimen of Ad26.COV2.S vaccine (Janssen, authorized on February $27,2021) .{ }^{3}$ Since the three vaccines were authorized at different times, differences in both followup time and demographics were observed (e.g., older individuals were eligible for vaccination prior to authorization of Ad26.COV2.S). We considered three sets of sensitivity analyses addressing any potential differences in waning of protection due to these factors. We aligned vaccination and follow-up time for the mRNA vaccines to Ad26.COV2.S, requiring the last vaccine dose to be on or after February 27, 2021 for all vaccines, and we also stratified cohorts by age and comorbidity score. Finally, we indirectly translated OR into VE estimates using incidence proportions from larger cohorts of vaccinated and unvaccinated individuals to provide a means of comparing durability of protection across vaccines and outcomes. Due to the low numbers of ICU admission cases, we restricted all sensitivity analyses to infections and hospitalizations.

For age-stratified analyses, we repeated the original analysis (excluding the ICU admission outcome due to small sample sizes) using the same procedures and methods and built models 
medRxiv preprint doi: https://doi.org/10.1101/2022.01.05.22268648; this version posted January 6, 2022. The copyright holder for this preprint (which was not certified by peer review) is the author/funder, who has granted medRxiv a license to display the preprint in perpetuity.

All rights reserved. No reuse allowed without permission.

separately for study participants 65 years and older and younger than 65 years of age. Similarly, for comorbidity-stratified analyses, we repeated our analyses for study participants with a comorbidity score less than two and a comorbidity score of two or greater. To assess waning of protection in cohorts aligned on vaccination and follow-up timing, only individuals who received their second dose of an mRNA vaccine on or after February 27, 2021 (the first day of eligibility for Ad26.COV2.S) were included. All other inclusion and exclusion criteria applied previously were maintained.

\section{Translating ORs to VE}

We estimated corresponding VE for each of the three vaccines for COVID-19 infection and COVID-19-related hospitalization outcomes. To estimate VE, we combined the OR for the outcomes for each of the three vaccines from the conditional logistic regression models described in the main manuscript (Table 3) with models to estimate outcome-specific baseline odds among all vaccinated individuals for each vaccine.

To estimate the baseline odds of each outcome (separately for each vaccine) we fitted a logistic regression model using all individuals vaccinated with the vaccine of interest who also met all other inclusion and exclusion criteria. We used this fitted logistic regression equation to find the odds of infection among all vaccinated individuals in the first month of follow-up (baseline). To harmonize baseline odds to the unvaccinated population we adjusted the model for age, sex, comorbidity score, and geographic location (state) according to the unvaccinated population demographics. Specifically, we categorized age (to 18-28, .., 89-98 categories) and comorbidity score (to -2-0, 0-2, 2-5, 5-25 categories) and calculated the proportion of unvaccinated individuals in each age, comorbidity score, sex, and state category. We used these categorical distributions to marginalize the estimated conditional probability from the fitted logistic regression equation to calculate the weighted probability of getting an outcome of interest in the first month, where the weighting was according to the unvaccinated population demographics. Under assumptions of independence the weighted probability of getting an outcome:

$$
\begin{aligned}
& P(Y=1)= \\
& \sum_{i, j, l, k} P\left(Y=1 \mid \text { age }_{i}, \text { sex }_{j}, c_{-} \text {score }_{l}, \text { state }_{k}\right) P\left(\text { age }_{i}\right) P\left(\text { sex }_{j}\right) P\left(c_{-} \text {score }_{l}\right) P\left(\text { state }_{k}\right),
\end{aligned}
$$

where $Y=1$ indicates that the outcome is observed.

Finally, we calculated the baseline odds as the weighted probability of having the outcome of interest in the first month over one minus that probability:

$$
\text { odd }_{\text {baseline }}=\frac{P(Y=1)}{1-P(Y=1)} \text {. }
$$

Next, we multiplied the baseline odds of outcome (among all vaccinated with the vaccine of interest) by the OR for the second, third, fourth, fifth, and sixth months of follow-up from the conditional logistic regression models used in the main analysis to approximate the odds of a positive test in the second, third, fourth, fifth, and sixth months respectively: 


$$
\text { odds }_{\text {month }_{k}}=\text { odds }_{\text {baseline }} O R_{\text {month }_{k}} \text {. }
$$

We used the odds of outcome in each month to calculate the probability of that outcome in the one-month period to approximate the incidence proportion (IP) for each month for the outcome of interest among those who had received the vaccine of interest:

$$
I P_{\text {vaccinated }_{\text {month }_{k}}}=\frac{\text { odd } \text { month }_{k}}{1+o d d s_{\text {month }}} \text {. }
$$

We next estimated the incidence proportion among the unvaccinated. First, we calculated IP for each calendar month in follow-up (February - August). Then, we calculated the proportion of cases in each month of follow-up by the calendar month in the vaccinated cohort (separately for each vaccine) and used these proportions as weights to calculate IP in unvaccinated for each month of follow-up separately:

$$
I P_{\text {unvaccinated }_{\text {month }_{k}}}=w_{F e b}^{\text {month }_{k}} I P_{\text {unvaccinated }_{F e b}}+\cdots+w_{\text {Aug }}^{\text {month }_{k}} I P_{\text {unvaccinated }_{\text {Aug }}}
$$

where $w_{J}^{\text {month }_{k}}$ - is the proportion of cases in month $k$ of follow up that happened in calendar month $J$. For example, consider Ad26.COV2.S vaccinated cohort infections outcome. There were $15 \%$ of cases in July and $85 \%$ in August in the month 5 since follow-up. Then, we calculate the IP for unvaccinated for month 5 of follow-up as

$I P_{\text {unvaccinated }_{\text {month }_{5}}}=0.15 I P_{\text {unvaccinated }_{\text {July }}}+0.85 I P_{\text {unvaccinated }_{\text {Aug }}}$.

We calculated the VE for each month as one minus the ratio of incidence proportions for the vaccinated as compared to the unvaccinated:

$$
V E_{\text {month }_{k}}=1-\frac{I P_{\text {vaccinated }_{\text {mont }_{k}}}}{\text { IP }_{\text {unvaccinated }} \text { month }_{k}} .
$$

Confidence intervals (95\%) for VE estimates were obtained by bootstrapping resampling over 1000 replicates. $^{4}$

Vaccine durability study comparison inclusion criteria

We compared our estimates of VE to similar studies from the literature and plotted these values for each vaccine and outcome (Figures S7-8). For inclusion, prior studies had to meet the following criteria:

1. Must be in a published or preprint study

2. Must report VE on at least one of the three COVID-19 vaccines currently in the US (Ad26.COV2.S, BNT162b2, and mRNA-1273)

3. VE could not be reported in aggregate across vaccines (e.g., VE could not be for "mRNA vaccines," or "any vaccine" and had to specify a single vaccine) 
medRxiv preprint doi: https://doi.org/10.1101/2022.01.05.22268648; this version posted January 6, 2022. The copyright holder for this preprint

(which was not certified by peer review) is the author/funder, who has granted medRxiv a license to display the preprint in perpetuity.

All rights reserved. No reuse allowed without permission.

4. VE must come from completed vaccine course (e.g., no VE percentages for initial dose in a two-dose series or booster shots only)

5. VE had to have at least two timepoints to qualify as a measure of durability over time

6. VE must be for infection or hospitalization outcomes

7. VE percentage at a specific timepoint had to be listed in a table

8. To reduce bias in comparing distinctly different cohorts between our study and others, we required that VE could not come from a special-interest population (e.g., high-risk groups like health care workers or immunocompromised patients) or a particular demographic category ( $\geq 65$ years of age) 
medRxiv preprint doi: https://doi.org/10.1101/2022.01.05.22268648; this version posted January 6, 2022. The copyright holder for this preprint (which was not certified by peer review) is the author/funder, who has granted medRxiv a license to display the preprint in perpetuity. All rights reserved. No reuse allowed without permission.

\section{Supplementary Results}

\section{$\underline{\text { Vaccine effectiveness }}$}

VE for infection and hospitalizations remained strong for all three vaccines throughout follow-up period (Tables S1-S2, and Figures S4 and S6). However, these results differed for BNT162b2, and mRNA-1273 when using the full available data (January 1, 2021 - September 7, 2021, Table S1 and Figure S4) or when aligning the cohort entry time to match the entry time of Ad26.COV2.S (February 27, 2021, Table S2 and Figure S6) especially for hospitalization. Leveraging the full available data, for infections, VE in the first month of follow-up was $0.74,0.88$, and 0.92 for Ad26.COV2.S, BNT162b2, and mRNA-1273 vaccines, respectively. Ad26.COV2.S showed stable VE over time. The mRNA vaccines had decreased VE by the final month of follow up with BNT162b2 decreasing to 0.71 and mRNA-1273 decreasing to 0.82 in month $6+$. Similar trends were observed when aligning the cohort entry date to February 27, 2021.

For COVID-19-related hospitalizations, using all available data, VE in the first month of followup was 0.81, 0.89, and 0.94 for Ad26.COV2.S, BNT162b2, and mRNA-1273 vaccines, respectively. In month 5+, Ad26.COV2.S VE against hospitalization was 0.76, and for BNT162b2, and mRNA-1273 in the 6+ month of follow-up VE against hospitalization was 0.52 and 0.90 respectively. When aligning the cohort entry date to February 27, 2021, for BNT162b2, and mRNA-1273, the waning in VE for BNT162b2 became less pronounced. Trends for mRNA-1273 VE remained similar to those previously observed (Table S2 and Figure S6).

These results confirm and extend estimations of peak VE (i.e., in the first month after full vaccination) for all three vaccines separately against infections and severe disease. The observed waning in VE against hospitalization for BNT162b2 requires further discussion. The apparent decline in VE over time is observed when the study cohort includes subjects vaccinated in January and February 2021. This may be driven, at least in part, by waning immune responses in older and more comorbid patients as observed in other sensitivity analyses. Further investigation is needed to fully understand the complete durability profile of each of the vaccines.

Our methods for translating OR to VE come with a number of limitations. First, we estimated incidence proportion from large cohorts of vaccinated and unvaccinated individuals where absolute case numbers likely represent underestimates, in part due to the potential for asymptomatic and unconfirmed infections. ${ }^{5-8}$ While this is not an issue if this is equally true for both vaccinated and unvaccinated groups, if providers tested or hospitalized individuals differently based on vaccine status, this may result in bias. Second, many COVID-19-related encounters in the US, including vaccination and tests, occurred in settings where they were not billed to any payer (e.g., mass vaccination clinics) and thus cannot be observed in claims. This can affect the results primarily via misclassification of unvaccinated individuals. This issue would be expected to result in an underestimate of VE. ${ }^{9,10}$ Finally, the cohorts differ by timing of events, and relatedly, their demographic makeup. As described above, we attempted to harmonize the baseline odds according to the demographic composition of the unvaccinated cohort. However, demographic differences persist and may limit the comparability of VE across vaccines. 
medRxiv preprint doi: https://doi.org/10.1101/2022.01.05.22268648; this version posted January 6, 2022. The copyright holder for this preprint (which was not certified by peer review) is the author/funder, who has granted medRxiv a license to display the preprint in perpetuity.

All rights reserved. No reuse allowed without permission.

\section{Supplementary Tables and Figures}

Table S1. Estimated VE against infections and hospitalizations by month of follow up for primary vaccine regimen for each vaccine.

\begin{tabular}{lcc}
\hline Ad26.COV2.S & $\begin{array}{c}\text { Breakthrough } \\
\text { Infection VE } \mathbf{9 5 \%} \text { CI) }\end{array}$ & $\begin{array}{c}\text { Hospitalization VE } \\
\mathbf{( 9 5 \%} \mathbf{C I})\end{array}$ \\
Month 1 & $0.74(0.72,0.75)$ & $0.81(0.76,0.82)$ \\
Month 2 & $0.68(0.63,0.70)$ & $0.75(0.64,0.80)$ \\
Month 3 & $0.74(0.70,0.76)$ & $0.72(0.60,0.79)$ \\
Month 4 & $0.74(0.70,0.75)$ & $0.76(0.65,0.83)$ \\
Month 5 or after & $0.74(0.69,0.75)$ & $0.76(0.64,0.82)$ \\
& & \\
BNT162b2 & & $0.89(0.88,0.90)$ \\
Month 1 & $0.88(0.87,0.88)$ & $0.86(0.84,0.88)$ \\
Month 2 & $0.84(0.83,0.84)$ & $0.75(0.71,0.79)$ \\
Month 3 & $0.79(0.78,0.80)$ & $0.64(0.58,0.71)$ \\
Month 4 & $0.78(0.77,0.80)$ & $0.52(0.44,0.61)$ \\
Month 5 & $0.75(0.73,0.76)$ & $0.52(0.43,0.61)$ \\
Month 6 or after & $0.71(0.69,0.73)$ & \\
mRNA-1273 & & $0.94(0.93,0.95)$ \\
Month 1 & & $0.93(0.91,0.94)$ \\
Month 2 & $0.92(0.91,0.92)$ & $0.90(0.88,0.92)$ \\
Month 3 & $0.89(0.88,0.90)$ & $0.90(0.87,0.92)$ \\
Month 4 & $0.87(0.86,0.88)$ & $0.89(0.86,0.92)$ \\
Month 5 & $0.86(0.85,0.87)$ & $0.90(0.87,0.92)$ \\
Month 6 or after & $0.85(0.83,0.86)$ & \\
\hline
\end{tabular}


Table S2. Estimated VE against infections and hospitalizations by month of follow-up for primary vaccine regimens in cohorts aligned by calendar vaccination time.

\section{Breakthrough Hospitalization VE Infection VE (95\% CI) $\quad(95 \% \mathrm{CI})$}

Ad26.COV2.S

$\begin{array}{lll}\text { Month 1 } & 0.74(0.72,0.75) & 0.81(0.76,0.82) \\ \text { Month 2 } & 0.68(0.63,0.70) & 0.75(0.64,0.81) \\ \text { Month 3 } & 0.75(0.70,0.76) & 0.73(0.61,0.80) \\ \text { Month 4 } & 0.74(0.70,0.75) & 0.77(0.66,0.83) \\ \text { Month 5 or after } & 0.74(0.70,0.76) & 0.77(0.64,0.83)\end{array}$

\section{BNT162b2}

Month 1

$0.89(0.88,0.89)$

$0.92(0.91,0.93)$

Month 2

$0.86(0.84,0.87)$

$0.90(0.87,0.92)$

Month 3

$0.86(0.84,0.87)$

$0.87(0.84,0.90)$

Month 4

$0.86(0.84,0.86)$

$0.86(0.82,0.89)$

Month 5 or after

$0.84(0.82,0.85)$

$0.84(0.79,0.88)$

mRNA-1273

Month 1

$0.92(0.91,0.92)$

$0.94(0.93,0.95)$

Month 2

$0.90(0.89,0.90)$

$0.93(0.91,0.94)$

Month 3

$0.90(0.89,0.91)$

$0.93(0.90,0.94)$

Month 4

$0.89(0.88,0.90)$

$0.93(0.91,0.95)$

Month 5 or after

$0.88(0.87,0.89)$

$0.93(0.91,0.95)$ 
medRxiv preprint doi: https://doi.org/10.1101/2022.01.05.22268648; this version posted January 6, 2022. The copyright holder for this preprint (which was not certified by peer review) is the author/funder, who has granted medRxiv a license to display the preprint in perpetuity.

All rights reserved. No reuse allowed without permission.

Figure S1. Study inclusion flowchart.

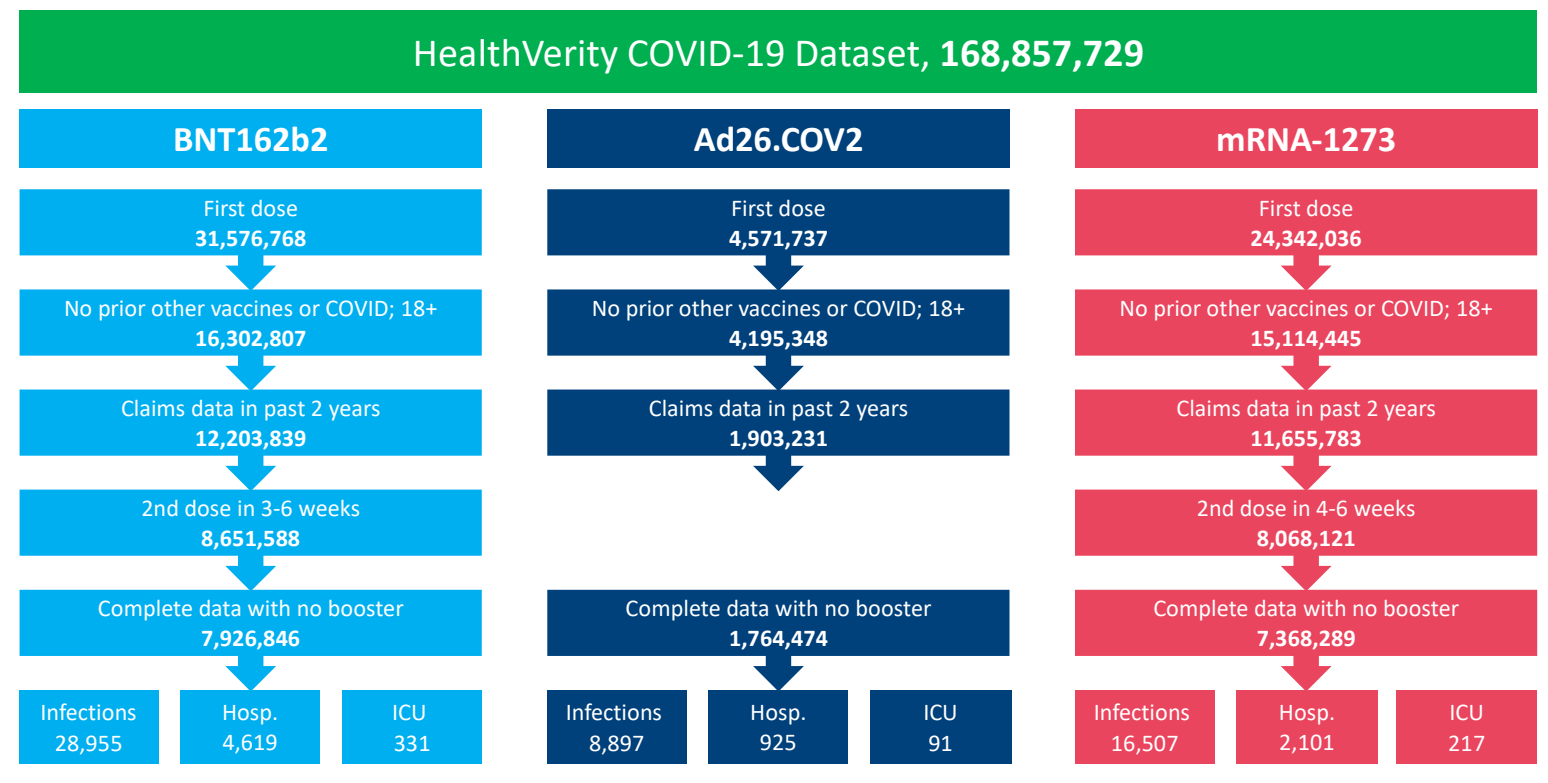


medRxiv preprint doi: https://doi.org/10.1101/2022.01.05.22268648; this version posted January 6, 2022. The copyright holder for this preprint (which was not certified by peer review) is the author/funder, who has granted medRxiv a license to display the preprint in perpetuity.

All rights reserved. No reuse allowed without permission.

Figure S2. OR and 95\% CI assessing durability of baseline vaccine protection against infections and hospitalizations where only persons with age 65 years or older and those with a comorbidity score $\geq 2$ are included in the analysis.

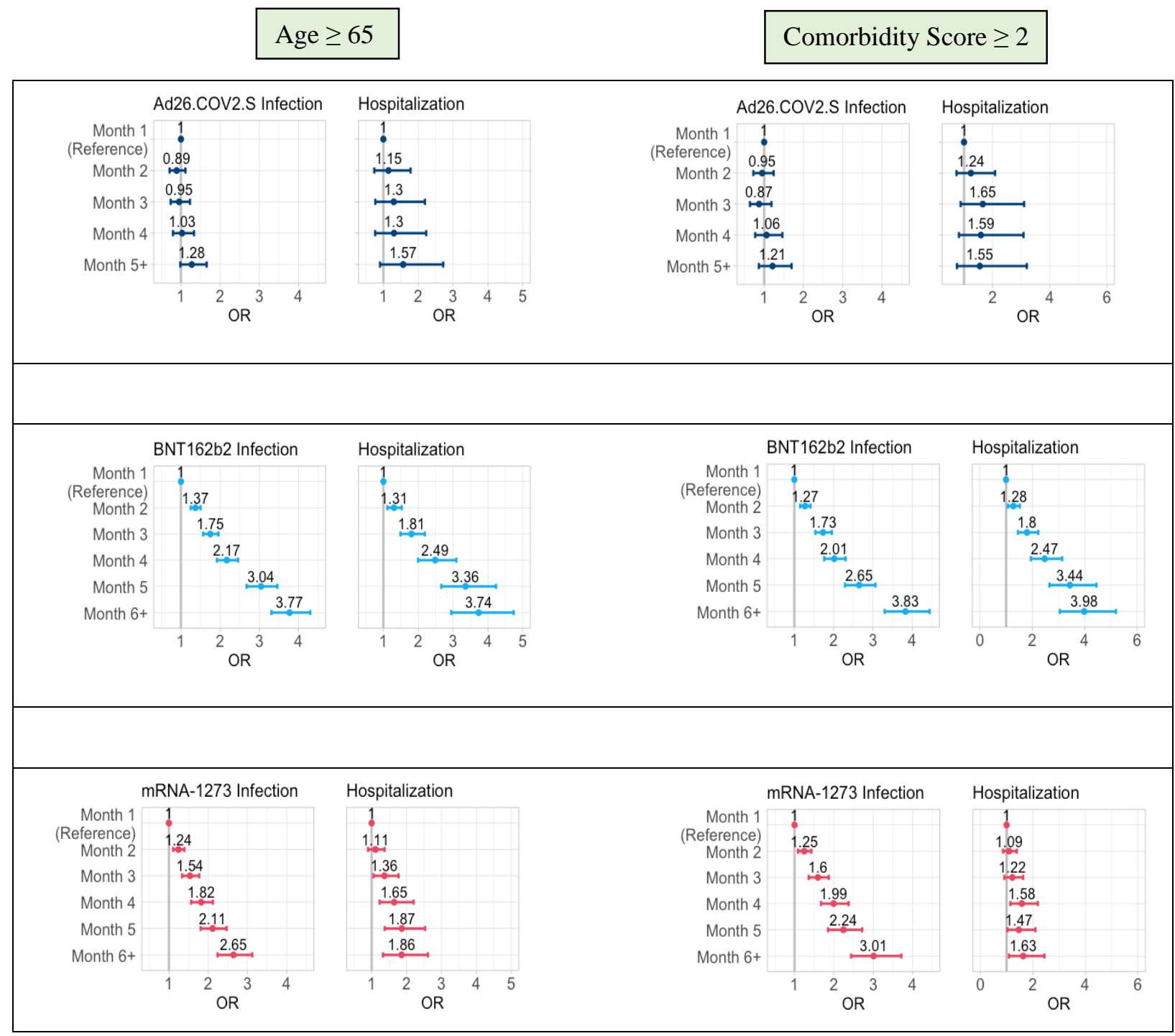


medRxiv preprint doi: https://doi.org/10.1101/2022.01.05.22268648; this version posted January 6, 2022. The copyright holder for this preprint (which was not certified by peer review) is the author/funder, who has granted medRxiv a license to display the preprint in perpetuity.

All rights reserved. No reuse allowed without permission.

Figure S3. OR and 95\% CI assessing durability of baseline vaccine protection against infections and hospitalizations where only persons with younger than 65 years and those with a comorbidity score $<2$ are included in the analysis.

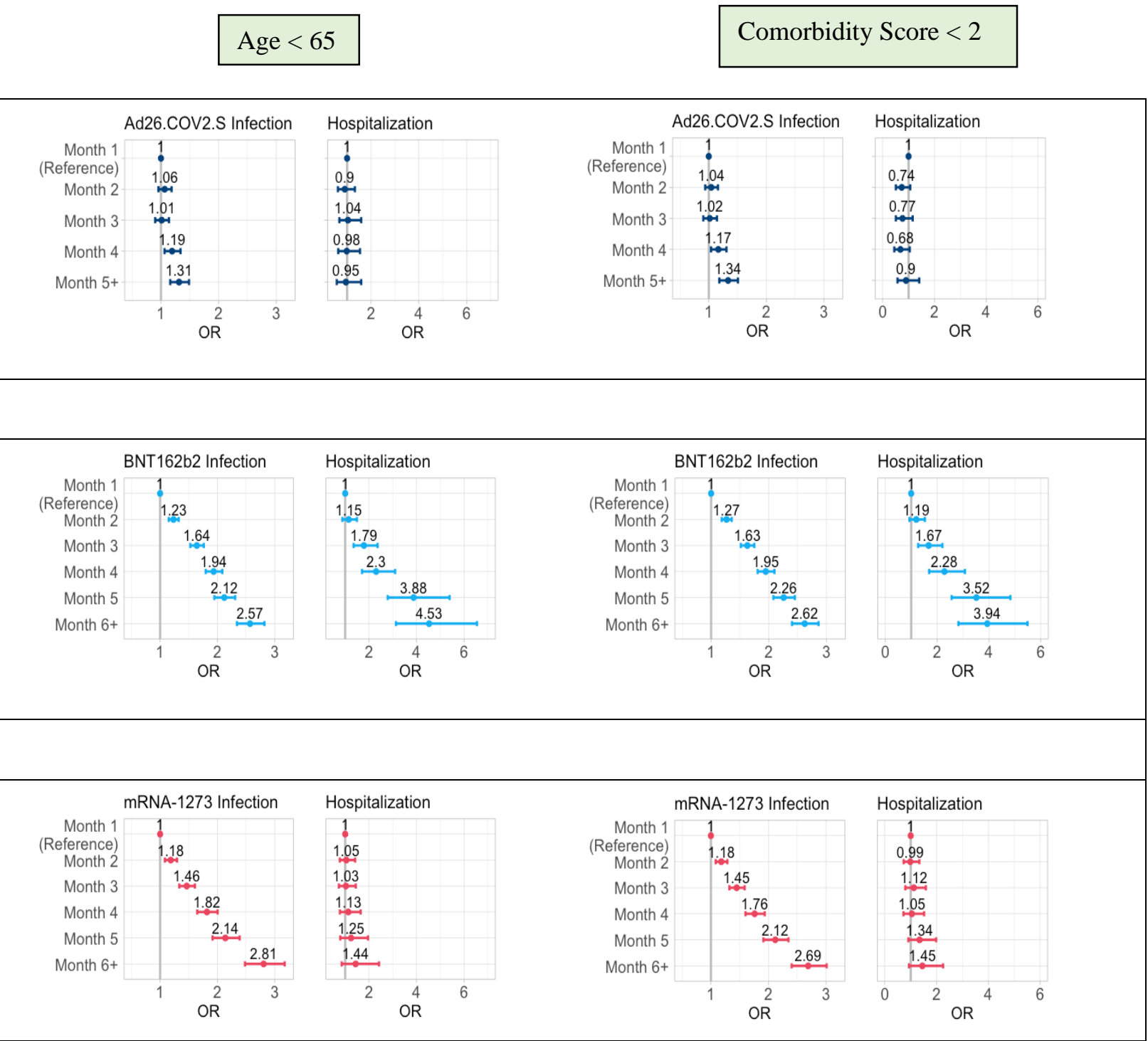


medRxiv preprint doi: https://doi.org/10.1101/2022.01.05.22268648; this version posted January 6, 2022. The copyright holder for this preprint (which was not certified by peer review) is the author/funder, who has granted medRxiv a license to display the preprint in perpetuity.

All rights reserved. No reuse allowed without permission.

Figure S4. Estimated VE and 95\% CI against infections and hospitalizations by month of follow up for primary vaccine regimen for each vaccine.

\section{a) Ad26.COV2.S}
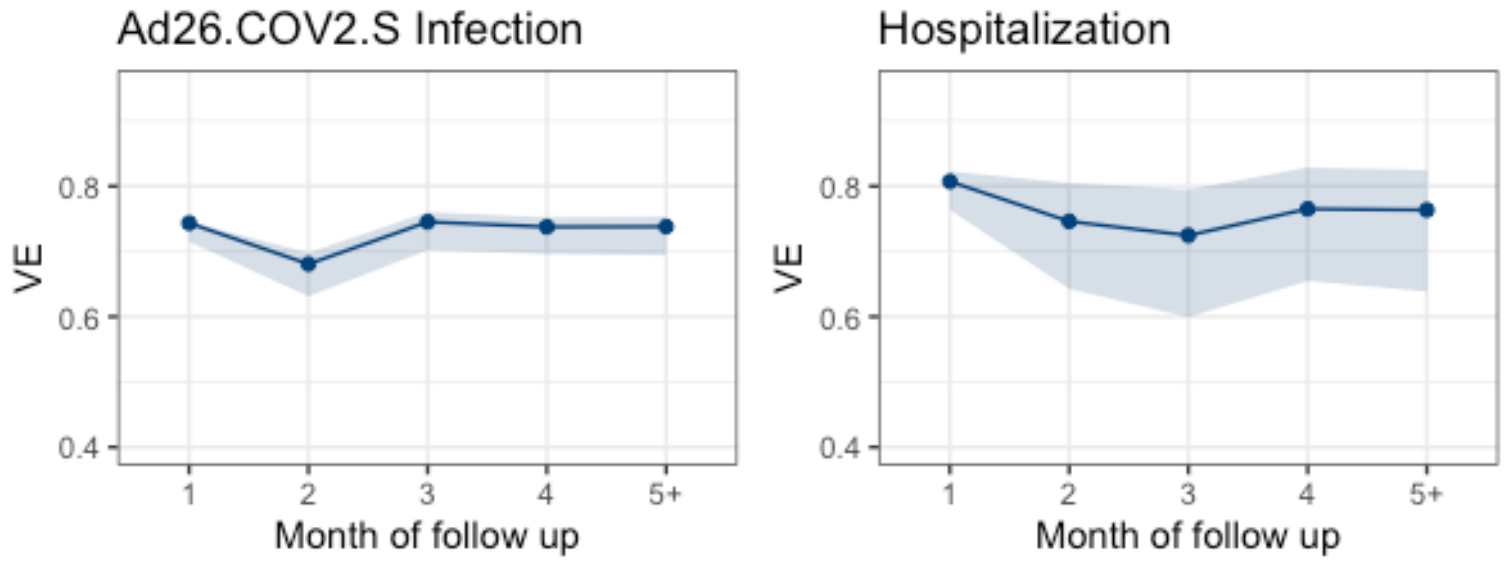

b) BNT162b2
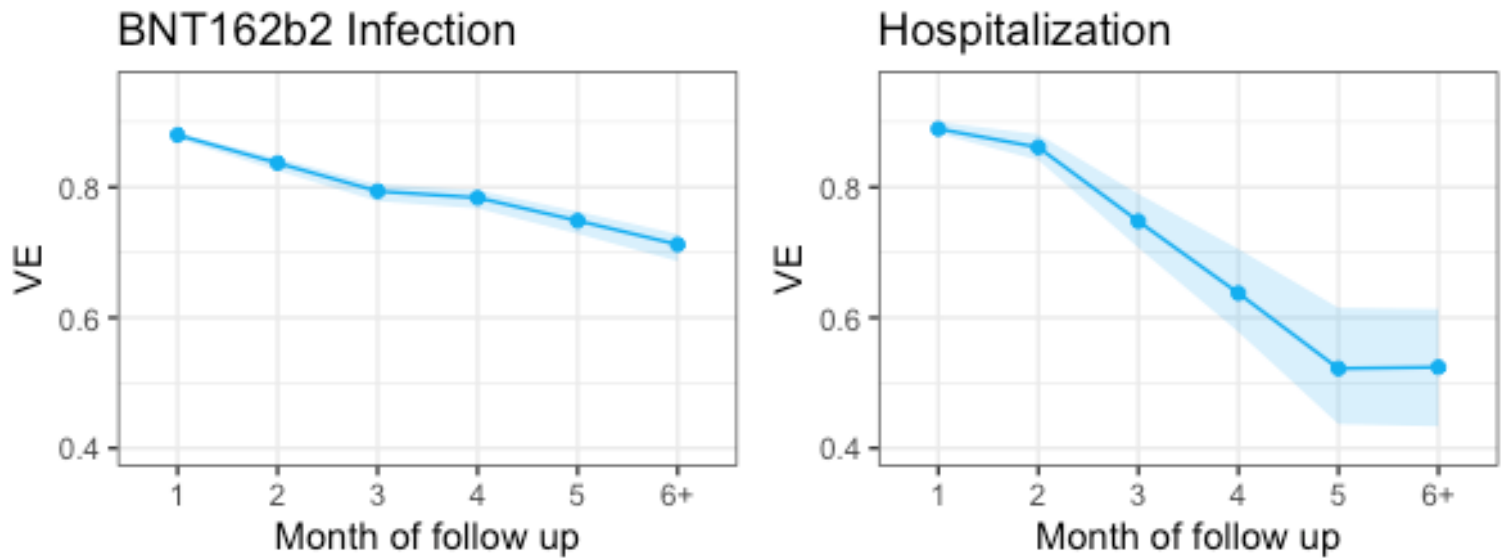

c) mRNA-1273
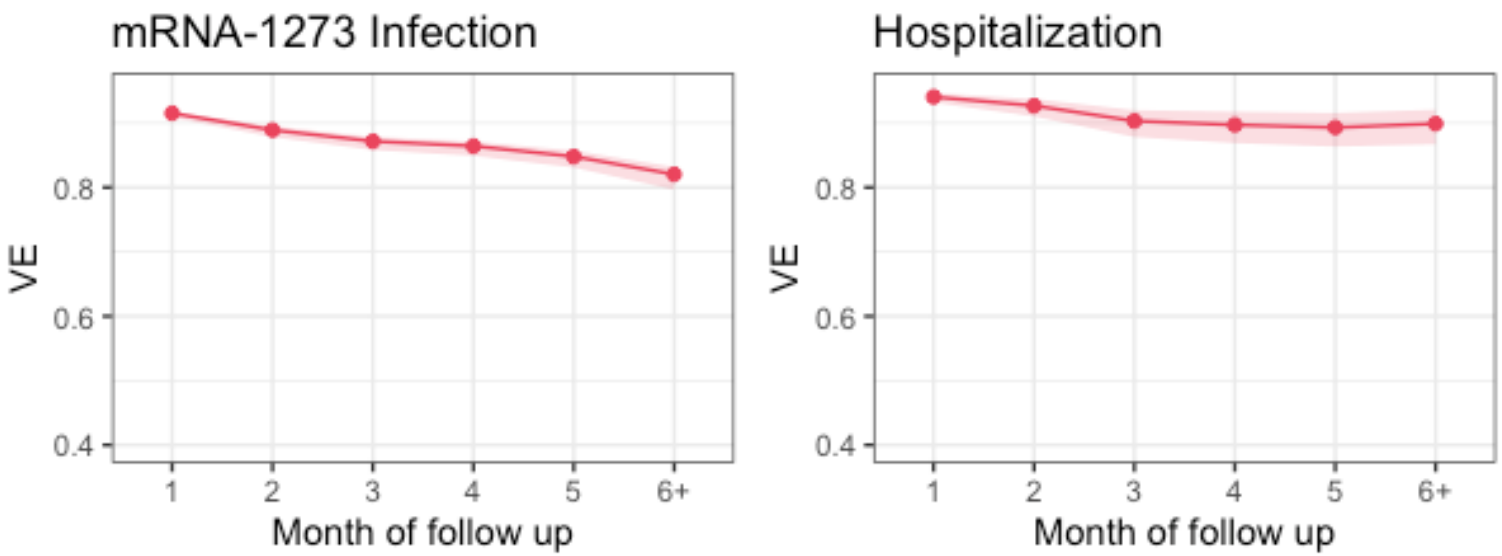
Figure S5. OR and 95\% CI assessing durability of baseline vaccine protection against infections and hospitalizations where last dose of vaccination was on or after February 27, 2021 for all three vaccines.

a) Ad26.COV2.S
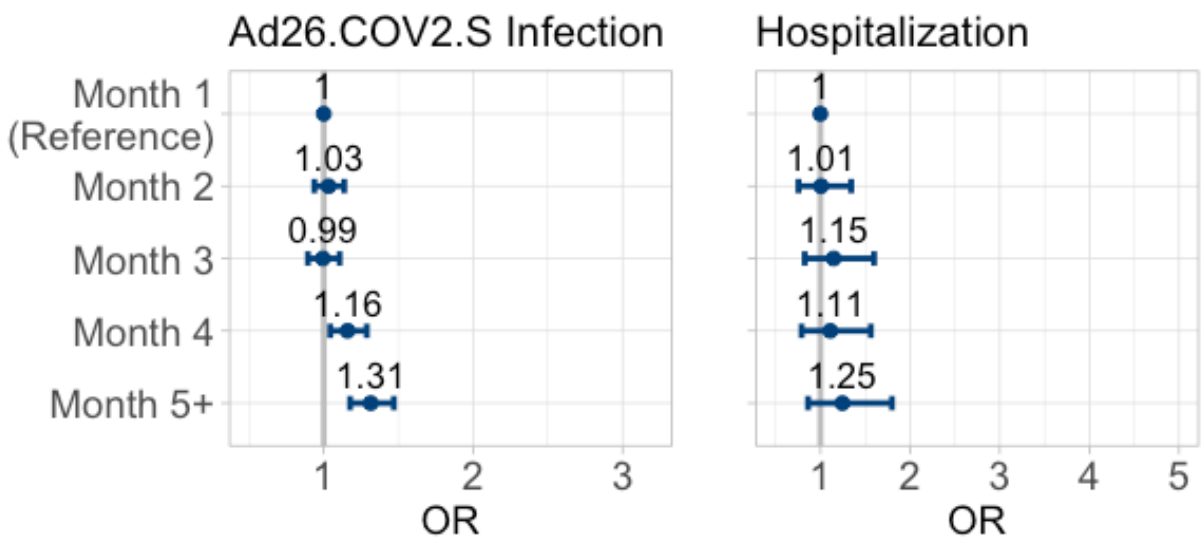

b) BNT162b2
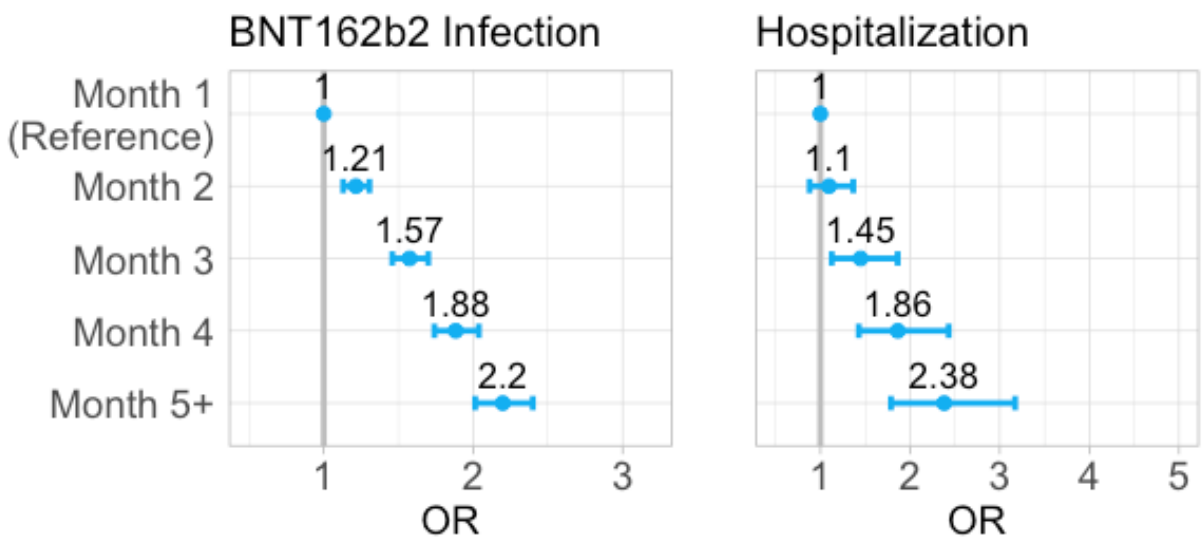

c) mRNA-1273
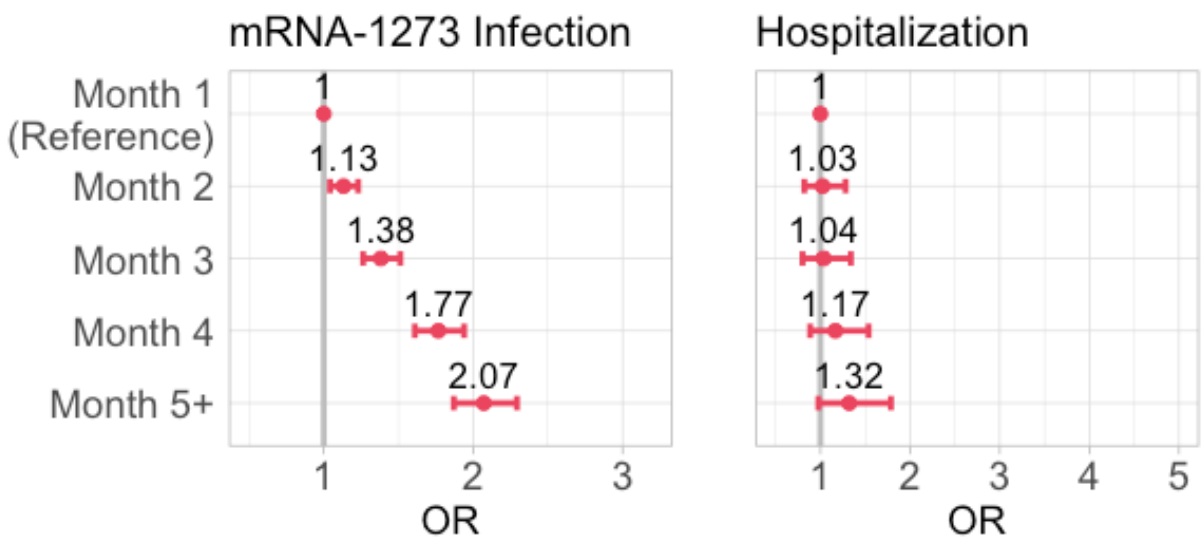
medRxiv preprint doi: https://doi.org/10.1101/2022.01.05.22268648; this version posted January 6, 2022. The copyright holder for this preprint (which was not certified by peer review) is the author/funder, who has granted medRxiv a license to display the preprint in perpetuity.

All rights reserved. No reuse allowed without permission.

Figure S6. Estimated VE and 95\% CI against infections and hospitalizations by month of follow-up for primary vaccine regimens in cohorts aligned where the last dose of vaccination was on or after February 27, 2021 for all three vaccines.

a) Ad26.COV2.S
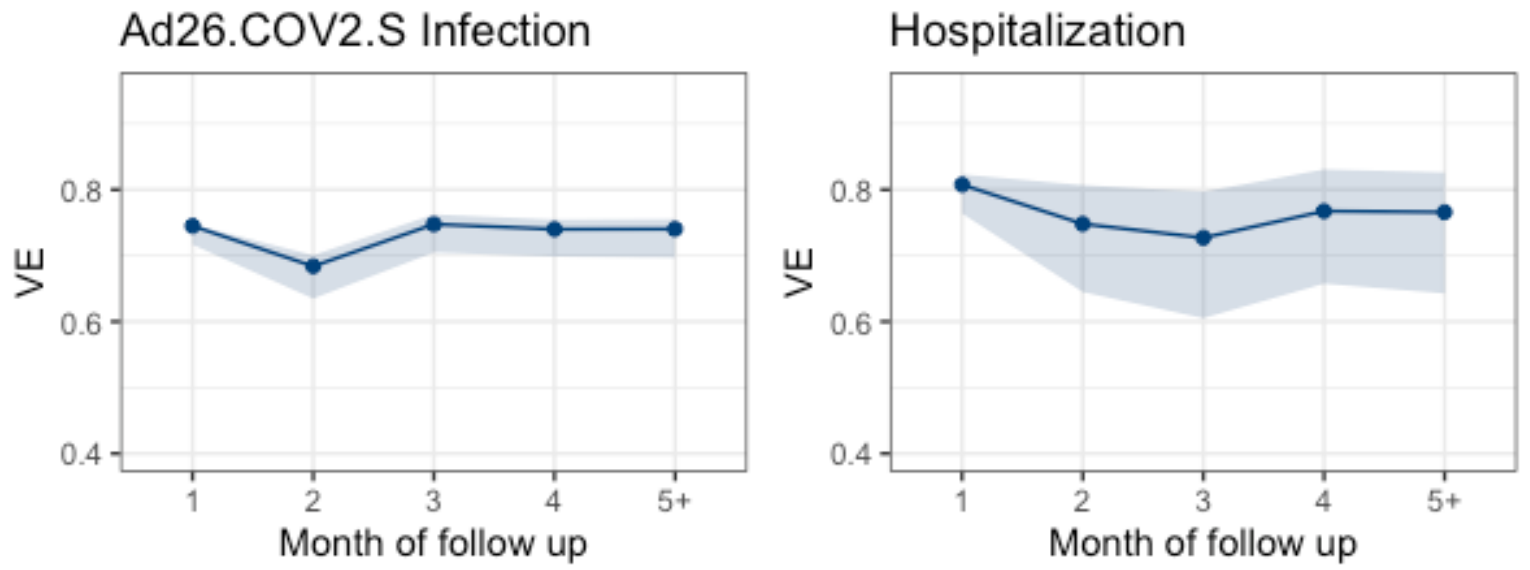

b) BNT162b2
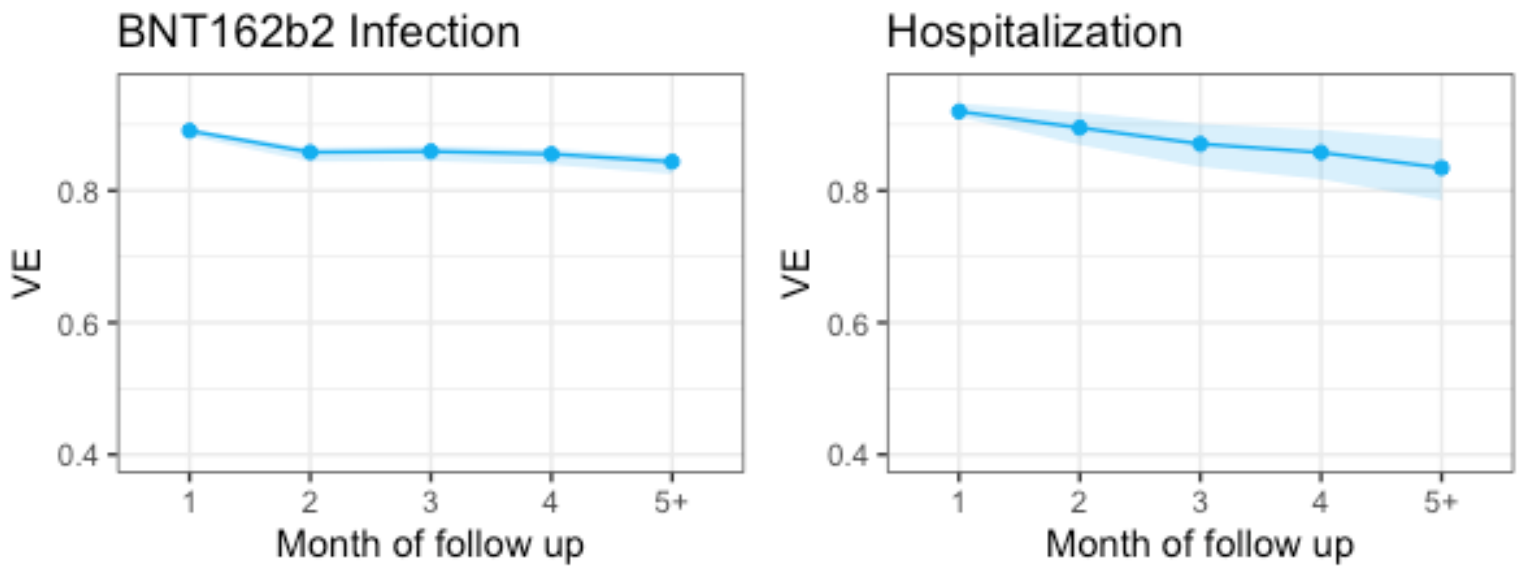

c) mRNA-1273
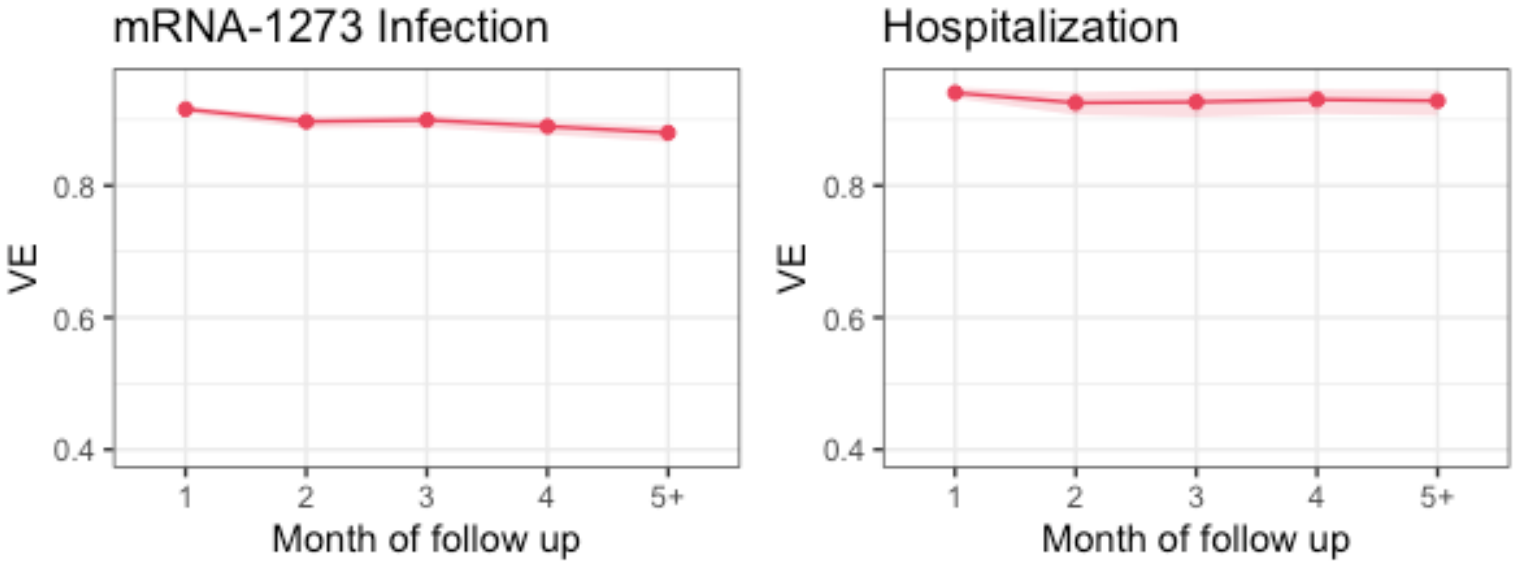
medRxiv preprint doi: https://doi.org/10.1101/2022.01.05.22268648; this version posted January 6, 2022. The copyright holder for this preprint (which was not certified by peer review) is the author/funder, who has granted medRxiv a license to display the preprint in perpetuity.

All rights reserved. No reuse allowed without permission.

Figure S7. Waning VE for infections across studies. Last vaccine dose referred to a single dose of Ad26.COV2.S or a second dose of BNT162b2 or mRNA-1273. Other studies included were Tartof et al. 2021, ${ }^{11}$ Skowronski et al. 2021, ${ }^{12}$ Lin et al. 2021, ${ }^{13}$ Chemaitelly et al., ${ }^{14}$ MartinezBas et al. 2021, ${ }^{15}$ and Andrews et al., 2021. ${ }^{16}$ Points reflected midpoints for each VE time interval reported (e.g., if VE was reported for days 14-28 following last vaccine dose, VE for that period was plotted at day 21).

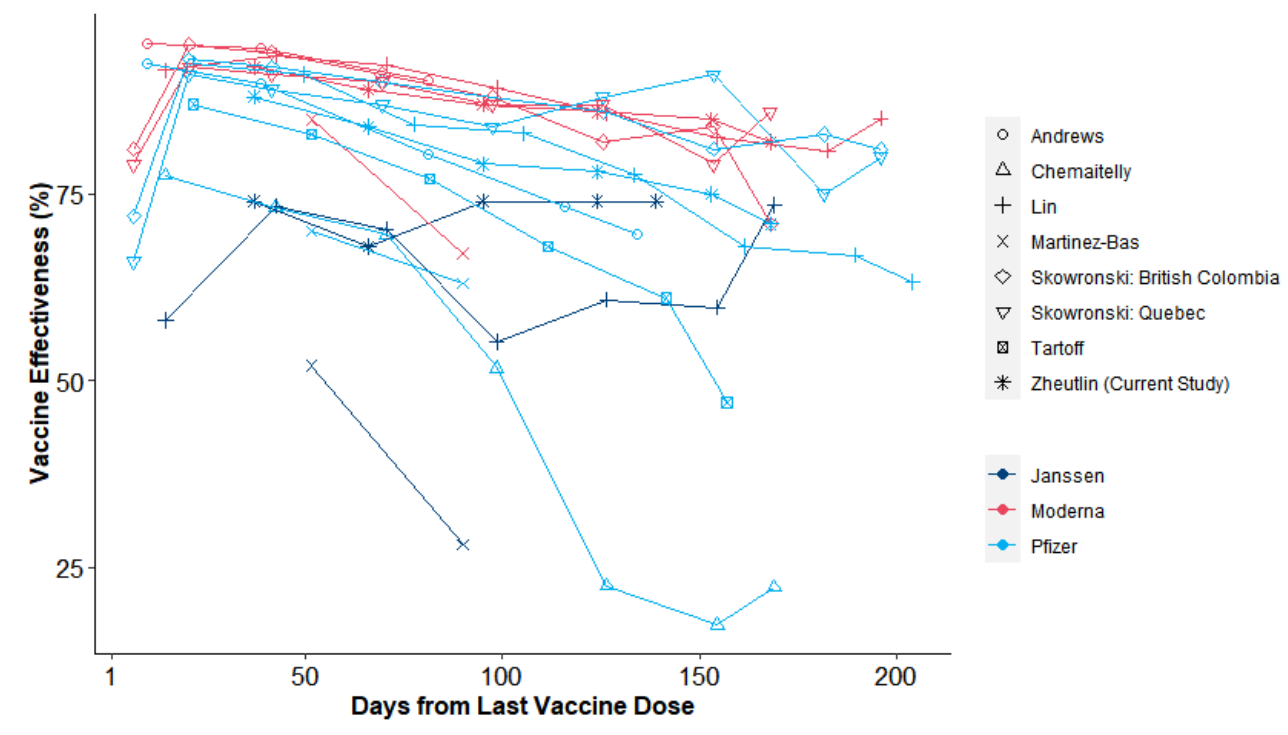


medRxiv preprint doi: https://doi.org/10.1101/2022.01.05.22268648; this version posted January 6, 2022. The copyright holder for this preprint (which was not certified by peer review) is the author/funder, who has granted medRxiv a license to display the preprint in perpetuity.

All rights reserved. No reuse allowed without permission.

Figure S8. Waning VE for hospitalizations across studies. Last vaccine dose referred to a single dose of Ad26.COV2.S or a second dose of BNT162b2 or mRNA-1273. Other studies included were Tartof et al. 2021, ${ }^{11}$ Skowronski et al. 2021, ${ }^{12}$ Lin et al. $2021,{ }^{13}$ Chemaitelly et al. ${ }^{14}$ Andrews et al., 2021, ${ }^{16}$ Self et al. 2021. ${ }^{17}$ Points reflected midpoints for each VE time interval reported (e.g., if VE was reported for days 14-28 following last vaccine dose, VE for that period was plotted at day 21).

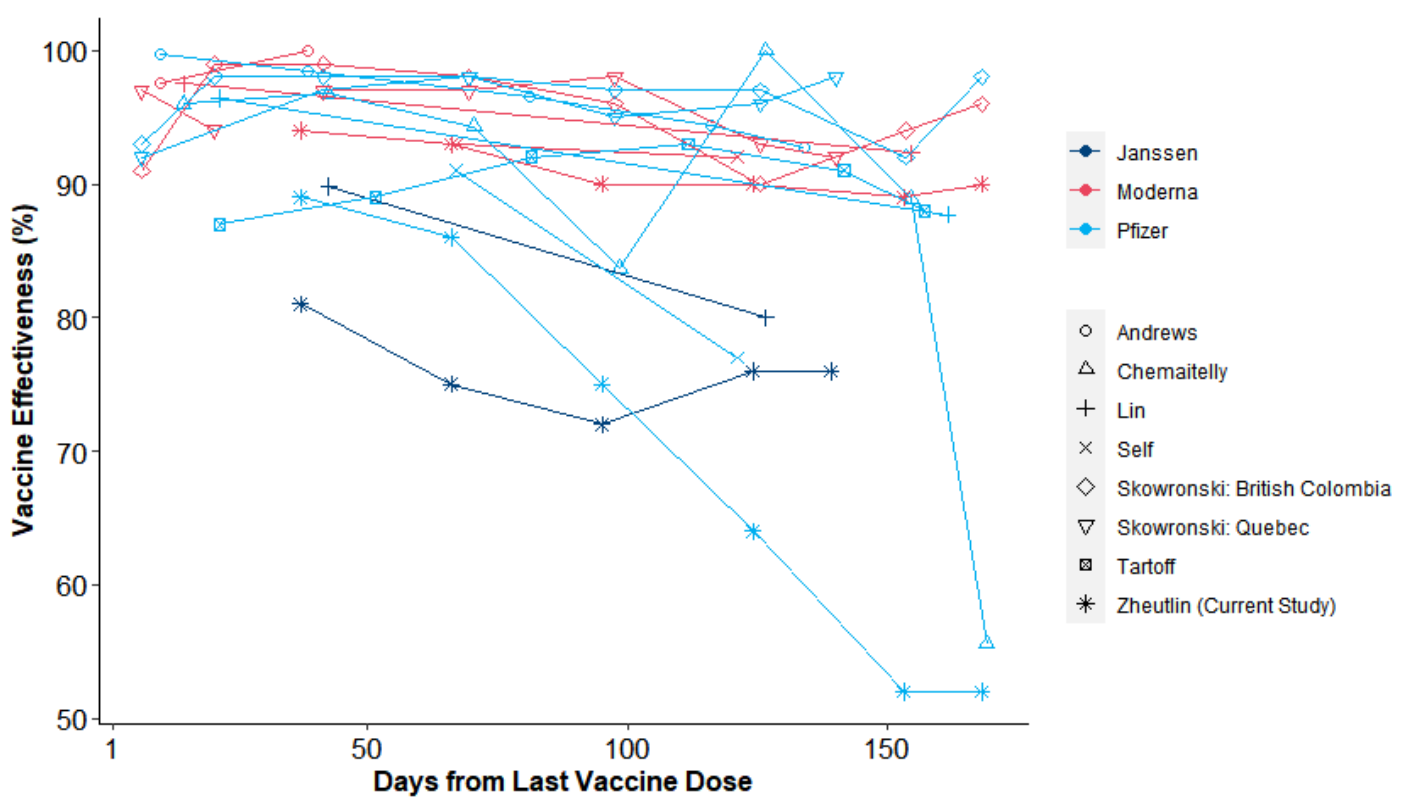


medRxiv preprint doi: https://doi.org/10.1101/2022.01.05.22268648; this version posted January 6, 2022. The copyright holder for this preprint

(which was not certified by peer review) is the author/funder, who has granted medRxiv a license to display the preprint in perpetuity.

All rights reserved. No reuse allowed without permission.

References

1. FDA Approves First COVID-19 Vaccine |FDA. Accessed October 5, 2021.

https://www.fda.gov/news-events/press-announcements/fda-approves-first-covid-19vaccine

2. Moderna COVID-19 Vaccine |FDA. Accessed October 5, 2021. https://www.fda.gov/emergency-preparedness-and-response/coronavirus-disease-2019covid-19/moderna-covid-19-vaccine

3. Janssen COVID-19 Vaccine |FDA. Accessed October 5, 2021. https://www.fda.gov/emergency-preparedness-and-response/coronavirus-disease-2019covid-19/janssen-covid-19-vaccine

4. Dixon, P.M. (2006). Bootstrap Resampling. In Encyclopedia of Environmetrics (eds A.H. El-Shaarawi and W.W. Piegorsch). https://doi.org/10.1002/9780470057339.vab028

5. Centers for Disease Control and Prevention. COVID data tracker: trends in number of COVID-19 vaccinations in the US. Accessed December 2, 2021.

6. Oran DP, Topol EJ. Prevalence of asymptomatic SARS-CoV-2 infection. Annals of Internal Medicine. 2021 Feb;174(2):286-7.

7. Johansson MA, Quandelacy TM, Kada S, Prasad PV, Steele M, Brooks JT, Slayton RB, Biggerstaff M, Butler JC. SARS-CoV-2 transmission from people without COVID-19 symptoms. JAMA network open. 2021 Jan 4;4(1):e2035057-.

8. Subramanian R, He Q, Pascual M. Quantifying asymptomatic infection and transmission of COVID-19 in New York City using observed cases, serology, and testing capacity. Proceedings of the National Academy of Sciences. 2021 Mar 2;118(9).

9. Polinski JM, Weckstein AR, Batech M, Kabelac C, Kamath T, Harvey R, Jain S, Rassen JA, Khan N, Schneeweiss S. Effectiveness of the Single-Dose Ad26. COV2. S COVID Vaccine. medRxiv. Posted September 16, 2021.

10. Thompson MG, Burgess JL, Naleway AL, Tyner HL, Yoon SK, Meece J, Olsho LE, Caban-Martinez AJ, Fowlkes A, Lutrick K, Kuntz JL. Interim estimates of vaccine effectiveness of BNT162b2 and mRNA-1273 COVID-19 vaccines in preventing SARSCoV-2 infection among health care personnel, first responders, and other essential and frontline workers - eight US locations, December 2020-March 2021. Morbidity and Mortality Weekly Report. 2021 Apr 2;70(13):495.

11. Tartof SY, Slezak JM, Fischer H, Hong V, Ackerson BK, Ranasinghe ON, Frankland TB, Ogun OA, Zamparo JM, Gray S, Valluri SR. Effectiveness of mRNA BNT162b2 COVID19 vaccine up to 6 months in a large integrated health system in the USA: a retrospective cohort study. The Lancet. 2021 Oct 16;398(10309):1407-16.

12. Skowronski DM, Setayeshgar S, Febriani Y, Ouakki M, Zou M, Talbot D, Prystajecky N, Tyson JR, Gilca R, Brousseau N, Deceuninck G. Two-dose SARS-CoV-2 vaccine effectiveness with mixed schedules and extended dosing intervals: test-negative design studies from British Columbia and Quebec, Canada. medRxiv. Posted October 26, 2021. doi: https://doi.org/10.1101/2021.10.26.21265397

13. Lin D, Gu Y, Wheeler B, Young H, Holloway S, Sunny SK, Moore Z, Zeng D. Effectiveness of Covid-19 Vaccines in the United States Over 9 Months: Surveillance Data from the State of North Carolina. medRxiv. Posted October 26, 2021.

doi:10.1101/2021.10.25.21265304 
medRxiv preprint doi: https://doi.org/10.1101/2022.01.05.22268648; this version posted January 6, 2022. The copyright holder for this preprint

(which was not certified by peer review) is the author/funder, who has granted medRxiv a license to display the preprint in perpetuity.

All rights reserved. No reuse allowed without permission.

14. Chemaitelly H, Tang P, Hasan MR, AlMukdad S, Yassine HM, Benslimane FM, Al Khatib HA, Coyle P, Ayoub HH, Al Kanaani Z, Al Kuwari E. Waning of BNT162b2 vaccine protection against SARS-CoV-2 infection in Qatar. New England Journal of Medicine. October 6, 2021; 385:e83.

15. Martínez-Baz I, Trobajo-Sanmartín C, Miqueleiz A, Guevara M, Fernández-Huerta M, Burgui C, Casado I, Portillo ME, Navascués A, Ezpeleta C, Castilla J. Product-specific COVID-19 vaccine effectiveness against secondary infection in close contacts, Navarre, Spain, April to August 2021. Eurosurveillance. 2021 Sep 30;26(39):2100894.

16. Andrews N, Tessier E, Stowe J, Gower C, Kirsebom F, Simmons R, Gallagher E, Chand M, Brown K, Ladhani S, Ramsay M. Vaccine effectiveness and duration of protection of Comirnaty, Vaxzevria and Spikevax against mild and severe COVID-19 in the UK. medRxiv. Posted October 6, 2021.

17. Self WH, Tenforde MW, Rhoads JP, et al. Comparative effectiveness of Moderna, PfizerBioNTech, and Janssen (Johnson \& Johnson) vaccines in preventing COVID-19 hospitalizations among adults without immunocompromising conditions - United States, March-August 2021. MMWR Morb Mortal Wkly Rep. Published online September 24, 2021:1337-1343. https://www.cdc.gov/mmwr 